\title{
Pacific offshore record of plinian arc volcanism in Central America: \\ 1. Along-arc correlations
}

\section{S. Kutterolf}

SFB574 at Kiel University/IFM-GEOMAR, Wischhofstrasse 1-3, D-24148 Kiel, Germany (skutterolf@ifm-geomar.de)

\author{
A. Freundt \\ SFB574 at Kiel University/IFM-GEOMAR, Wischhofstrasse 1-3, D-24148 Kiel, Germany \\ IFM-GEOMAR, Wischhofstrasse 1-3, D-24148 Kiel, Germany
}

W. Peréz

SFB574 at Kiel University/IFM-GEOMAR, Wischhofstrasse 1-3, D-24148 Kiel, Germany

\section{T. Mörz}

MARUM, Leobener Strasse, D-28359 Bremen, Germany

\section{U. Schacht}

SFB574 at Kiel University/IFM-GEOMAR, Wischhofstrasse 1-3, D-24148 Kiel, Germany

CO2CRC, Australian School of Petroleum, University of Adelaide, Adelaide, South Australia 5005, Australia

\section{H. Wehrmann}

SFB574 at Kiel University/IFM-GEOMAR, Wischhofstrasse 1-3, D-24148 Kiel, Germany

\author{
H.-U. Schmincke \\ SFB574 at Kiel University/IFM-GEOMAR, Wischhofstrasse 1-3, D-24148 Kiel, Germany \\ IFM-GEOMAR, Wischhofstrasse 1-3, D-24148 Kiel, Germany
}

[1] We collected 56 marine gravity cores from the Pacific seafloor offshore Central America which contain a total of 213 volcanic ash beds. Ash-layer correlations between cores and with their parental tephras on land use stratigraphic, lithologic, and compositional criteria. In particular, we make use of our newly built database of bulk-rock, mineral, and glass major and trace element compositions of plinian and similarly widespread tephras erupted since the Pleistocene along the Central American Volcanic Arc. We thus identify the distal ashes of 11 Nicaraguan, 8 El Salvadorian, 6 Guatemalan, and 1 Costa Rican eruptions. Relatively uniform pelagic sedimentation rates allow us to determine ages of 10 previously undated tephras by their relative position between ash layers of known age. Linking the marine and terrestrial records yields a tephrostratigraphic framework for the Central American volcanic arc from Costa Rica to Guatemala. This is a useful tool and prerequisite to understand the evolution of volcanism at a whole-arc scale.

Components: 13,993 words, 11 figures, 1 table.

Keywords: marine tephra; Central America; plinian volcanism; offshore geology; submarine slides; mud mounds. 
Index Terms: 8455 Volcanology: Tephrochronology (1145); 8428 Volcanology: Explosive volcanism; 3002 Marine Geology and Geophysics: Continental shelf and slope processes (4219).

Received 15 March 2007; Revised 25 September 2007; Accepted 31 October 2007; Published 8 February 2008.

Kutterolf, S., A. Freundt, W. Peréz, T. Mörz, U. Schacht, H. Wehrmann, and H.-U. Schmincke (2008), Pacific offshore record of plinian arc volcanism in Central America: 1. Along-arc correlations, Geochem. Geophys. Geosyst., 9, Q02S01, doi:10.1029/2007GC001631.

Theme: Central American Subduction System

Guest Editors: G. Alvarado, K. Hoernle, and E. Silver

\section{Introduction}

[2] Ash layers intercalated with marine sediments in the Pacific seafloor offshore Central America are the distal deposits of plinian and ignimbriteforming eruptions at the Central American Volcanic Arc (CAVA). The magnitudes of past events, which are separated by long time intervals, are difficult to determine on land because exposure of deposits is often incomplete and the Pacific coast is only a few tens of kilometers downwind from the volcanoes such that most of the westward dispersed tephra is emplaced on the seafloor. Hence the mostly non-erosive submarine environment may preserve a complete record of large eruptions in which the intercalation of deposits from different volcanic sources facilitates the relative and absolute timing of their activities.

[3] A number of earlier studies used ODP/DSDP and gravity cores to investigate ash layers offshore Central America [Bowles et al., 1973; Cadet et al., 1982a, 1982b; Drexler et al., 1980; Hahn et al., 1979; Ledbetter, 1982; Pouclet et al., 1985]. These studies identified the Los Chocoyos ash from Atitlán Caldera in Guatemala as a widespread marker bed, which can be found even at very distal sites offshore Costa Rica to Ecuador and in the Caribbean basin. Other correlations, however, remained uncertain because of the lack of reference data from deposits on land and the analytical limitation to major elements.

[4] Using the results from on-land studies of the deposits of highly explosive eruptions at the CAVA [Chiesa, 1991; Chiesa et al., 1992; Hart and Steen-McIntyre, 1983; Kempter et al., 1996; Mehringer et al., 2005; Newhall, 1987; Peterson and Rose, 1985; Rose, 1987a, 1987b; Rose et al., 1999; Vogel et al., 2004, 2006] and our own field work in Nicaragua [Freundt et al., 2006a;
Kutterolf et al., 2007a], El Salvador and Guatemala, allowed us to build a database of bulk-rock, mineral and glass compositions and eruption ages. Such compositional data together with lithologic and petrographic criteria as well as stratigraphic constraints facilitates the correlation of marine ash layers with tephras from individual eruptions on land.

[5] During our cruises R/V METEOR M54 and M66 and R/V SONNE SO173 we collected 56 sediment gravity cores of 1.5 to $11 \mathrm{~m}$ in length along the Central American Trench from Costa Rica to southern Guatemala, with core locations on the continental slope and on the incoming Cocos plate (Figure 1). In this contribution we aim to correlate ash layers between these cores and with their source volcanoes on land to build up an overall Central American tephrostratigraphy and to constrain unknown eruption ages. The companion paper part 2 discusses volcanological implications for individual eruptions and the whole arc, and part 3 addresses implications for forearc geological features.

\section{Geological Setting}

[6] The Central American Volcanic Arc (CAVA) lies $150-200 \mathrm{~km}$ away from the Middle America trench where the Cocos plate subducts beneath the Caribbean plate at a convergence rate of 70 $90 \mathrm{~mm} / \mathrm{a}$ [Barckhausen et al., 2001; DeMets, 2001]. The CAVA is bounded in the north by a zone of strike slip faults near the Mexico-Guatemala border that separates the Caribbean and North American plates [Carr et al., 2007; GuzmanSpeziale et al., 1989]. The volcanic arc is tectonically segmented, with offsets at segment boundaries such that the trench-arc distance decreases northward on each segment. Arc magmatic compositions vary along the CAVA in a systematic fashion attributed to changing conditions in the subduction system [Carr 


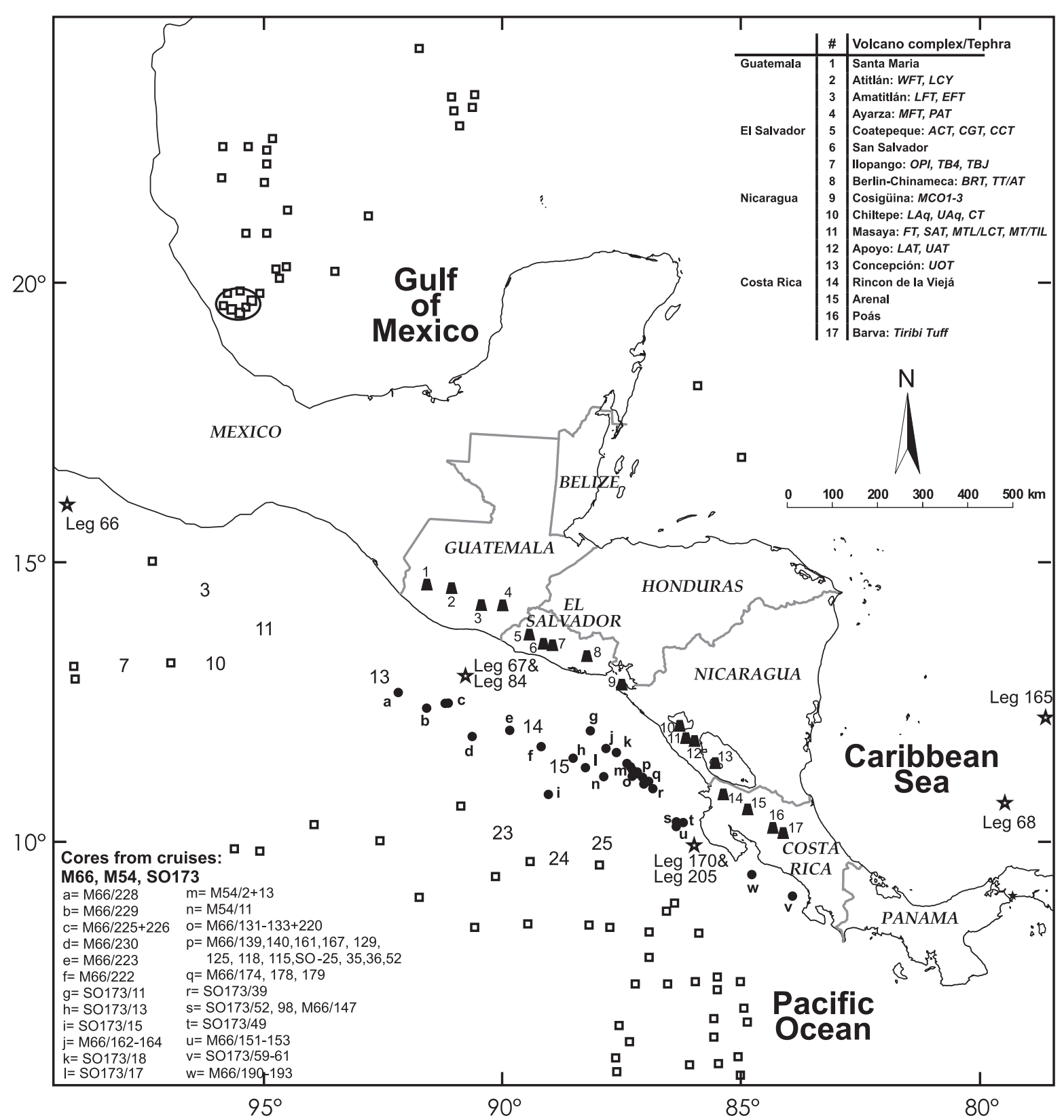

Figure 1. Map of Central America showing the CAVA volcanoes, core locations of ODP/DSDP (stars), and gravitycore positions (squares) of Bowles et al. [1973], Rabek et al. [1985], and Ledbetter [1985], which all contain the D/Y8-Layer (Los Chocoyos Tephra). Encircled cores in the Gulf of Mexico contain the Y5-Layer [Rabek et al., 1985]. Numbers in the Pacific Ocean identify cores of Bowles et al. [1973], in which we can correlate ash beds to onshore tephras. Volcano (trapeze) numbers and names and tephra acronyms are given in the top right corner: WFT, W-Fall Tephra; LCY, Los Chocoyos Tephra; LFT, L-Fall Tephra; EFT, E-Fall Tephra; MFT, Mixta Tephra; PAT, Pinos Altos Tephra; ACT, Arce Tephra; CGT, Congo Tephra; CCT, Conacaste Tephra; OPI, Older pumice Ilopongo; TB4, Terra Blanca 4 Tephra; TBJ, Terra Blanca Joven Tephra; BRT, Blanca Rosa Tephra; TT/AT, Twins/ A-Fall Tephra; MCO1-3, Mafic Cosigüina Tephras; Laq, Lower Apoyeque Tephra; Uaq, Upper Apoyeque Tephra; CT, Chiltepe Tephra; FT, Fontana Tephra; SAT, San Antonio Tephra; MTL/LCT, Masaya Triple Layer/La Concepción Tephra; MT/TIL, Masaya Tuff/Ticuantepe Lapilli; LAT, Lower Apoyo Tephra; UAT, Upper Apoyo Tephra; UOT, Upper Ometepe Tephra. Dots show core positions of R/V METEOR cruises M66 and M54 and R/V SONNE cruise SO173 along and across the trench; letters identify cores listed at bottom left. 
et al., 1990, 2003, 2007; Carr, 1984; Feigenson and Carr, 1986; Feigenson et al., 2004; Hoernle et al., 2002; Patino et al., 1997, 2000], in addition to local variations due to magmatic differentiation. Such compositional diversity is extremely useful for stratigraphic correlations.

[7] Upper Pleistocene (since 500 ka) to Holocene arc volcanism of El Salvador and Guatemala includes quite a number of large-magnitude eruptions of highly evolved, silicic magmas, mostly from caldera volcanoes [Rose et al., 1999]. These are the Ayarza, Amatitlán and Atitlán calderas in Guatemala, and the Berlin-Chinameca complex, Ilopango Caldera, and Coatepeque Caldera in El Salvador (Figure 1). However, there are also Nicaraguan volcanoes that produced moderately large-magnitude plinian eruptions: Concepción volcano, Apoyo Caldera, Masaya Caldera, Chiltepe volcanic complex, and Cosigüina volcano [Freundt et al., 2006a; Kutterolf et al., 2007a; Scott et al., 2006]. Within the time interval considered here, the 322 ka Tiribi Tuff [Pérez et al., 2006] is the only known large-magnitude event in Costa Rica. However, as we will show below, there are additional widespread plinian fall deposits from Costa Rican volcanoes yet not identified onshore.

\subsection{On-Land Tephrostratigraphy}

[8] The last three decades have seen a number of publications investigating predominantly the tephrostratigraphic successions of single volcanoes or eruptions and limited areas in Central America [Bice, 1985; Bonis et al., 1970; Borgia and van Wyk de Vries, 2003; Bosse et al., 1976; Commision Ejecutiva Hidroelectrica del Rio Lempa (CEL), 1992, 1995; Chiesa, 1991; Chiesa et al., 1992; Drexler et al., 1980; Hahn et al., 1979; Hart, 1983; Hazlett, 1987; Kempter et al., 1996; Koch and McLean, 1975; McKnight and Williams, 1997; Newhall, 1987; Peterson and Rose, 1985; Pullinger, 1998; Reynolds, 1987; Rose, 1987a; Rose et al., 1982, 1987, 1999; Scott et al., 2006; Self et al., 1989; Sussman, 1985; Vogel et al., 2004, 2006; Williams, 1983; Wundermann, 1982; Wundermann and Rose, 1984]. We have recently revised and extended some of that work in Nicaragua [Freundt et al., 2006a; Kutterolf et al., 2007a; Pérez and Freundt, 2006; Wehrmann et al., 2006], El Salvador and Guatemala. We have used these studies to collect samples for our compositional database in Central America.

[9] About 50 Upper Pleistocene to recent eruptions were of sufficiently large intensities and magnitudes to have distributed ash widely across the adjacent Pacific. Prominent time markers in these successions are the L-Tephra $(\sim 191 \mathrm{ka})$ and Los Chocoyos Tephra $(\sim 84 \mathrm{ka})$ in Guatemala [e.g., Drexler et al., 1980; Rose et al., 1999], the Arce $(\sim 72 \mathrm{ka})$, Congo $(\sim 53 \mathrm{ka})$ and Tierra Blanca Joven tephras $(\sim 1.5 \mathrm{ka})$ in El Salvador [e.g., $C E L$, 1992; Hart, 1983], and the Upper Apoyo ( 25 ka) and Chiltepe tephras ( $\sim 2 \mathrm{ka})$ in Nicaragua [Freundt et al., 2006a; Kutterolf et al., 2007a]. We have sampled all these tephras for bulk-rock, glass and phenocryst chemical analyses. We also sampled Pleistocene to recent tephras in Costa Rica supported by G.A. Alvarado (ICE, San Jose), among which the 322 ka Tiribi Tuff [Hannah et al., 2002; Pérez et al., 2006] is a prominent time marker.

\subsection{Previous Offshore Tephrostratigraphic Work}

[10] Tephra studies along the Central American subduction zone extend back to the early 1980s, when DSDP Leg 67 recovered 186 ash layers in the Pacific offshore Guatemala and was later complemented by DSDP Leg 84 [Cadet et al., 1982a; Pouclet et al., 1985]. At both legs one ash layer was correlated firmly with the Los Chocoyos Ash from Lake Atitlán while other ash beds were tentatively associated with the 1902 eruption of Santa Maria volcano and the Pinos Altos tephra from Ayarza caldera [Cadet et al., 1982a; Drexler et al., 1980; Pouclet et al., 1985; Rose et al., 1979, 1982]. Two DSDP sites from Leg 68 (502 and 503) and ODP Leg 165 (Figure 1) revealed 2019 volcanic ash layers, which probably originated from eruptions in Central America and possibly the Antilles, Mexico, and even the Andes, since the Early Miocene [Jordan et al., 2006; Ledbetter, 1982; Sigurdsson, 1997]. Farther south offshore Costa Rica, Clift et al. [2005] sampled around 50 marine ashes of the same age range in the cores of ODP Legs 170 and 205 and correlated them preliminarily to mostly Costa Rican sources. Bowles et al. [1973] distinguished three principal areas of ash deposition in the eastern equatorial and southeastern Pacific Ocean using 128 volcanic ash samples from 56 piston cores covering the past $\sim 300 \mathrm{ka}$ (Figure 1). On the basis of minor and trace element bulk rock compositions these authors tentatively identified source volcanoes in Guatemala, El Salvador, Nicaragua, Colombia, and Ecuador without correlating marine ash beds to specific single eruptions. Later, Ledbetter [1985] identified the $84 \mathrm{ka}$ Los Chocoyos ash and the $119 \mathrm{ka}$ T-tephra from Guatemala in these marine sections. 

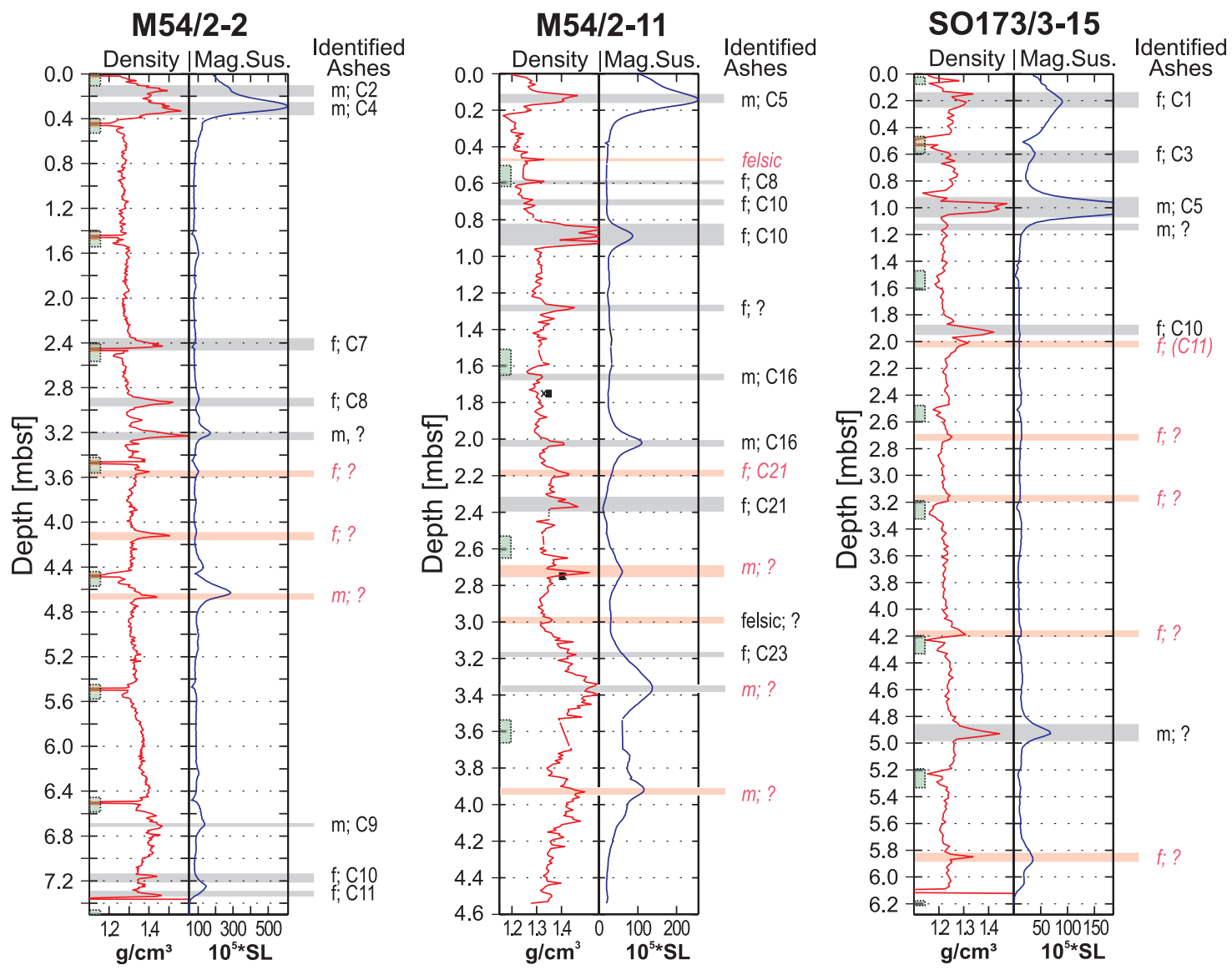

increasing distance from arc

Figure 2. Density and magnetic susceptibility logs of selected cores offshore Nicaragua (see Figure 1 for positions; left to right increasing distance from arc). Sharp drops in density values and green bars mark core segment boundaries. Gray shading marks visually identified ash layers. Pink bars mark ash horizons missed during visual inspection on board, emphasizing the importance of logging. C\# refer to correlated ashes; ?, not correlated; m, mafic ash; f, felsic ash.

[11] When analyzing a first subset of our cores collected offshore Nicaragua and Costa Rica, we were able to correlate marine ash beds with older tephra deposits from the Guayabo Caldera near active Rincón del la Vieja volcano in Costa Rica, and with the Upper Apoyo, Upper Apoyeque and Fontana tephras in Nicaragua [Kutterolf et al., 2007b].

\section{Methods}

\subsection{Marine Core Sampling and Logging}

[12] From 2002 to 2005, we have used R/V METEOR cruises M66, M54 and R/V SONNE cruise SO 173 to collected 56 sediment cores along both sides of the trench from Costa Rica to Guatemala between $9^{\circ} 12^{\prime} \mathrm{N} / 84^{\circ} 39^{\prime} \mathrm{E}$ and $12^{\circ} 15^{\prime} \mathrm{N} / 91^{\circ} 30^{\prime} \mathrm{E}$ (Table $\mathrm{S}^{1}{ }^{1}$ ) at $3500-4000 \mathrm{~m}$ water depth on the oceanic plate and 1200-2500 $\mathrm{m}$ water depth on the lower continental slope, with lengths of 3.5 to $11 \mathrm{~m}$ bsf. Since there is a high risk of erosion by turbidity currents on the continental slope, we have used high-resolution bathymetric maps [Ranero et al., 2005] to choose core locations on ridges outside submarine canyons. The core positions lie at $150-370 \mathrm{~km}$ perpendicular distance from the CAVA (Figure 1) and all cores together contain 213 ash horizons.

[13] Visual core descriptions were complemented by core logging including $\mathrm{P}$ wave velocity, sediment densities from gamma-ray attenuation and

${ }^{1}$ Auxiliary materials are available in the HTML. doi:10.1029/ 2007GC001631. 
magnetic susceptibility. Such logging helped to identify ash mixed with pelagic sediment in addition to distinct ash layers (Figure 2). Magnetic susceptibility logging was most useful as it reflects the volume fraction of magnetic minerals [Blum, 1997] and thus is a measure of the concentration of ash. We cut bulk slice samples from clean ash layers on board and separated the volcanic material from samples of mixed sediment in the laboratory. Separated glass shards and minerals were then used in geochemical microanalyses.

\subsection{Primary Versus Reworked Ash and Ash Pods}

[14] The formation of ash lenses, also known as "pods," in marine sediments is attributed to a variety of mechanisms [Hunt and Najman, 2003] such as burrowing by benthic dwellers [Cambray et al., 1993], redeposition by strong water currents or slumping on steep bottom topography [Fujioka, 1986]. Operating at the seafloor soon after emplacement, such processes probably do not disturb the geochemical integrity of the reworked tephra [Hunt and Najman, 2003]. However, there are abundant slumps detached from several meters deep scarps on the continental slope of Central America (W. B. Brückmann and R. Harders, personal communication, 2006); ash in slumped sediments may be a mixture from several source layers. Turbidity currents from such events could cross the trench and reach the incoming plate, which is also dissected by numerous steep bend fault scarps that may locally collapse [Ranero et al., 2005]. As a consequence, we analyzed a large number of glass shards and minerals from layers and pods in order to check if the geochemical data is either welltrended (i.e., displaying a clear fractionation/ evolution signal) or relatively homogenous. We use compositional criteria to distinguish between primary ash layers, primary (homogenous) and secondary (inhomogeneous) pods, and between weakly (homogeneous ash composition) and strongly reworked ash-sediment mixed layers (containing $>50 \%$ glass shards). Since active tectonics on the outer rise may duplicate or invert entire stratigraphic sections [e.g., Anderson et al., 1984], we particularly watched for signs of unconformity and cross-checked correlations to be mutually consistent.

\subsection{Analytical Techniques}

[15] Glass shards and crystals from marine ash beds and matrix glass and phenocrysts of pumice samples from land were analyzed by electron microprobe (EMP) for major and minor elements. For the reference samples from land, at least 5 medium-sized lapilli have been crushed to ash grain size; the $63-125 \mu \mathrm{m}$ and $125-250 \mu \mathrm{m}$ fractions were then used for spot analysis of the glass shards. EMP analyses were conducted on epoxy embedded samples with a CAMECA SX 50 wavelength dispersive electron microprobe at IFM-GEOMAR, Kiel, using $15 \mathrm{kV}$ accelerating voltage, a beam defocused to $5 \mu \mathrm{m}$ with currents of 10 and $6 \mathrm{nA}$ for basaltic and felsic glass, respectively, and counting times of 30 to $60 \mathrm{~s}$ for most major elements and 60 to $100 \mathrm{~s}$ for the trace elements and backgrounds. Natural and synthetic glasses and minerals were used as standards for calibration. Standard deviation is $<0.5 \%$ for major and $<3 \%$ for minor elements. All analyses are normalized to $100 \%$ to eliminate the effects of variable post-depositional hydration.

[16] Since glass compositions of some tephras overlap significantly in major elements, we also analyzed trace element concentrations of glass shards by Laser Ablation Inductively Coupled Plasma-Mass Spectrometry (LA-ICP-MS) at the University of Frankfurt am Main (Institute of Mineralogy) using a Merchantek LUV213TM petrographic laser microprobe in conjunction with a Finnigan MAT ELEMENT2TM high-resolution ICP double-focusing mass spectrometer. The laser beam was set to $30 \mu \mathrm{m}$ in diameter and operated in ultra-violet modus at $213 \mathrm{~nm}$ using Q-switched laser energy of $2 \mathrm{~mJ}$ and a $5 \mathrm{~Hz}$ repetition rate. International standard glasses were measured every ten samples to monitor accuracy and silica and calcium concentrations, measured by EMP, are used as an internal standard to calibrate the trace element analyses. The thin (20 to $100 \mu$ thick) glass shards limit measurement duration and we selected the most discriminative elements for analysis: $\mathrm{Rb}, \mathrm{Sr}, \mathrm{Y}, \mathrm{Zr}, \mathrm{Nb}, \mathrm{Cs}, \mathrm{Ba}, \mathrm{La}, \mathrm{Ce}, \mathrm{Nd}, \mathrm{Sm}, \mathrm{Eu}$, Gd, Dy, Er, Yb, Hf, Ta, Th, and U. Average precision and accuracy estimates based on replicate analyses of synthetic NIST standards and USGS BCR-2 glasses are $<10 \%$ for most elements.

[17] All microanalyses aimed at the center of glass shards because variable submarine alteration [Kutterolf et al., 2007b] causes elemental exchange at the surface of single glass shards first [e.g., Schacht, 2005]. Average compositions of marine and onshore tephras are given in auxiliary material Table S2. 


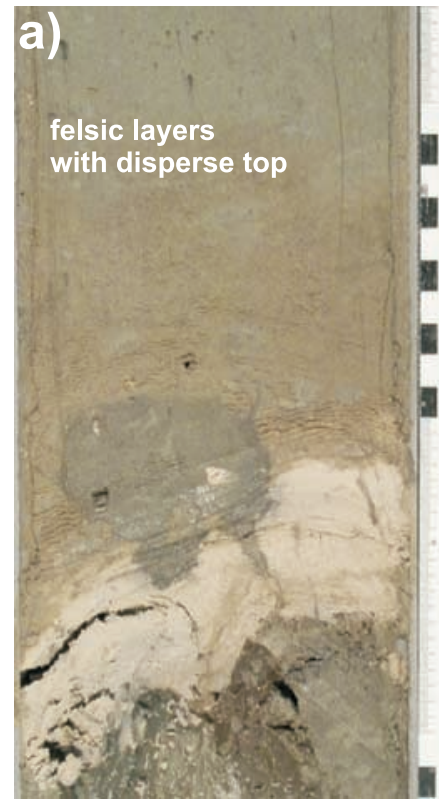

M66/3-229 534-523 cm bsf

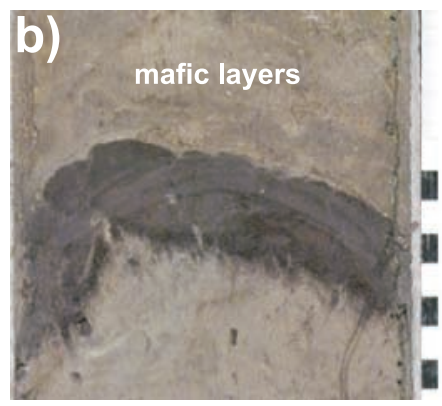

M66/3-230 207-203 cm bsf
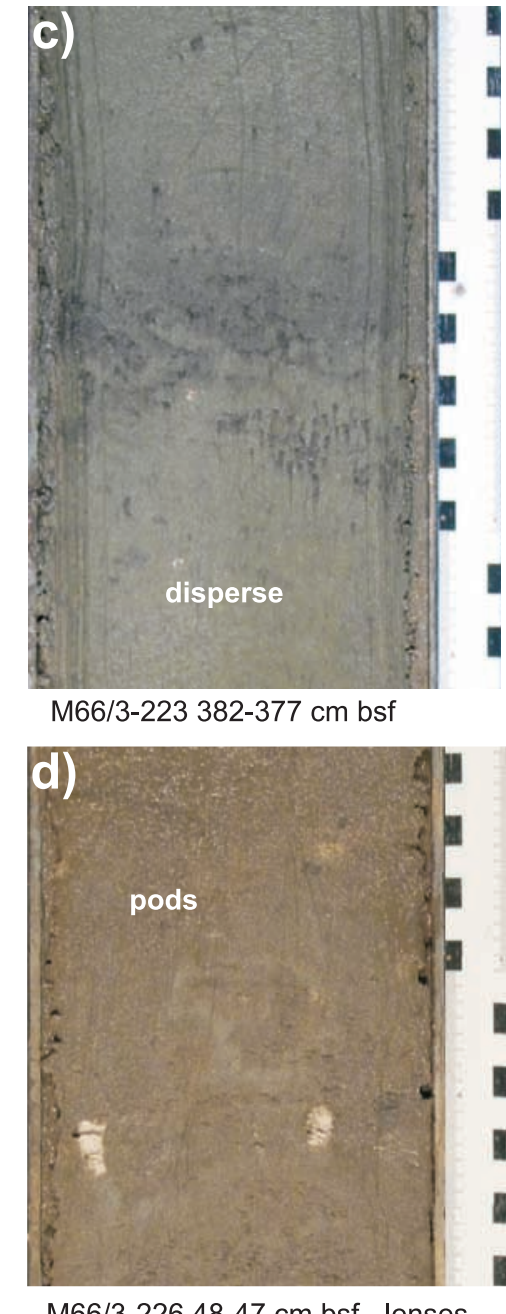

M66/3-226 48-47 cm bsf - lenses

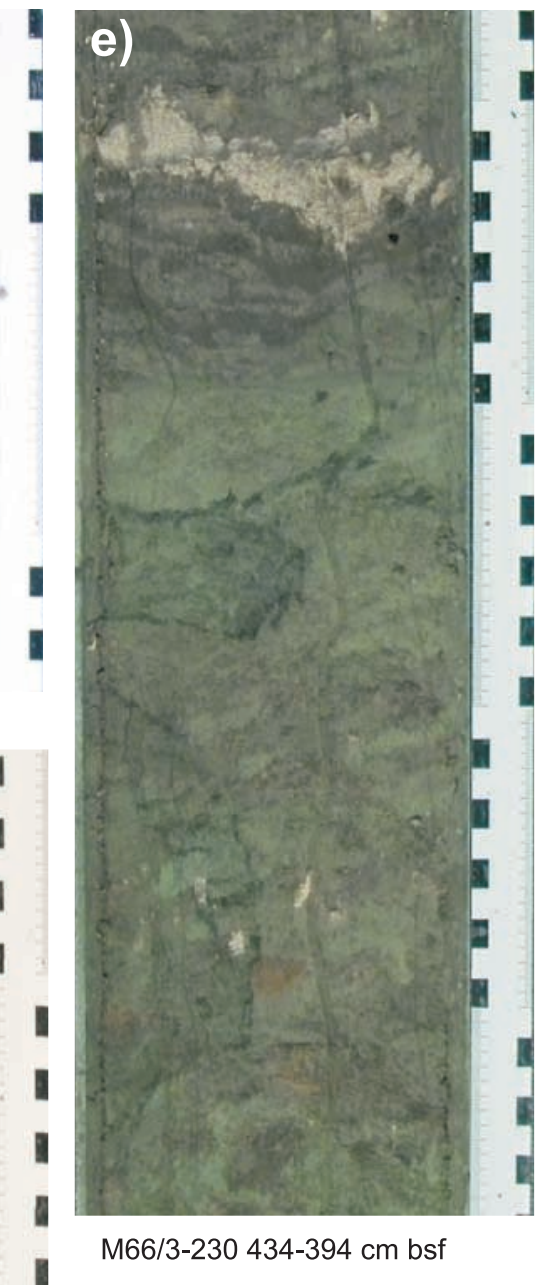

M66/3-230 434-394 cm bsf

Figure 3. Photographs of selected ash layers. (a and b) Primary ash layers of different compositions. The competent layers are disturbed by the corer. (c) Mafic ash of homogenous composition mixed with sediment. (d) Small felsic ash pods. (e) Felsic ash layer underlain by sediment with reworked clay clasts.

\subsection{Correlation Techniques}

[18] Ash layer correlations are based on modal and chemical (glass and mineral) compositions as well as on structural and lithological characteristics and stratigraphic relationships. We determined the proportions of particulate components (minerals, glass shards, volcanic lithics, other clastic sediment, biogenic material) and the vesicularity and vesicle texture of pumice fragments in smear slides under the microscope. Such observations helped to support correlations while glass chemical compositions proved to be the most distinctive characteristic.

[19] Correlations based on the glass compositions of the tephras on land hark back to at least 30 EMP as well as 5 to 10 LA-ICP-MS analyses per tephra layer, using a minimum of three samples per tephra deposit. For the marine ash layers, 30 EMP and 1 to 9 LA-ICP-MS analyses of glass shards for each sample have been carried out. In addition, we use published compositional data of ash layers from Ledbetter [1985], Bowles et al. [1973] and Rabek et al. [1985] to also attempt some correlations with other cores collected in marine basins around Central America. We also investigated tephra correlations by multielement hierarchical cluster analysis (squared Euclidean distance, farthest neighbor method) similar to Jordan et al. [2006] and Bice [1985] using the SPSS version 14 software.

\section{Results}

\subsection{General Description of Cores}

[20] The cores collected from offshore Central America contain a total of 213 ash bearing hori- 
zons, including 133 distinct ash layers, intercalated with pelagic sediment ranging 1 to $12 \mathrm{~cm}$ in thickness (Figure 3). Of the 133 distinct primary ash layers in all cores, 69 are light gray to white felsic ashes, 24 are gray layers of intermediate composition and 40 are black layers of mafic compositions.

[21] Widespread mafic ash beds account for 37\% of the total ash-bed assemblage offshore Nicaragua, compared to $20 \%$ offshore El Salvador and Guatemala. The mafic ash layers are characterized by high magnetic susceptibility and high-density logging values whereas felsic ashes have low or negative magnetic susceptibility values but also high density values (Figure 2). Ash-containing sediment layers show marked differences in porosity, water content, and grain size compared to ash-free clay sediment. Some ash layers are significantly hardened compared to their host sediment due to diagenetic processes and were tilted and bent during coring. Below some ash layers, the underlying sediment is discolored and hardened to a depth of up to $6 \mathrm{~cm}$; this probably reflects incipient cementation by silica or carbonate derived from the ash bed. Unconformable and/or inclined bedding of ash beds due to erosion, creep or slumping of sediment is rare offshore Nicaragua both on the continental slope and the incoming plate (Figure 3e). In some cores, especially those from the incoming plate, bioturbation occurred. In total, the ratio of primary ash layers to pods and dispersed ash in sediment is 82:49:25 offshore Nicaragua, and 50:13:7 offshore the northern part of Central America. The chemical composition of glass shards suggest that offshore Nicaragua 45\% (50\% offshore El Salvador and Guatemala) of pods and $30 \%$ of sediment layers with dispersed ash (85\% offshore El Salvador and Guatemala) occur in the correct stratigraphic context, with redeposition of ash having occurred soon after primary emplacement.

[22] In general, ash layers have a sharp basal contact to underlying pelagic clay but a gradual transition with overlying ash-bearing pelagic sediment (up to $50 \mathrm{~cm}$ ), and many are normally graded in grain size. Felsic white ash is mainly $(>90 \mathrm{vol} \%)$ composed of fresh, clear, colorless, glass shards varying from highly vesicular, pumiceous textures with commonly elongated bubbles to angular blocky, cuspate, flat and y-shaped shards with nearly no bubbles (Figure 4). Grain size ranges from fine to coarse ash (up to $\mathrm{mm}$ size). The mineral assemblages comprise plagioclase, clinopyroxene, some hornblende, olivine and orthopyr- oxene. Plagioclase is the dominant crystal phase but some ash beds, especially in the northern cores, are dominated by biotite and quartz, which occurs in the most-evolved felsic layers (see Table S2a). In the southern cores toward Nicaragua, the ferromagnesian phases are pyroxenes with traces of amphibole. Dark-gray mafic ash layers consist predominantly of dark brown glass shards. Most of the glass shards have blocky shapes and are medium to poorly vesicular (Figure 4). Some mafic ash layers, however, also contain highly vesicular, tubular, brownish glass shards (Figure 4). The fraction of shards in the mafic ash layers that are altered at their rims increases toward older marine ash beds. The mineral assemblages of the mafic tephras include plagioclase, pyroxene and some olivine. In contrast with the felsic ash layers, the mafic ash layers contain significantly more biogenic material (up to $10 \%$ ), typically planktonic foraminifers that were probably trapped by the ash sinking through the water column.

[23] The dark-olive-green pelagic sediment is silty to sandy clay that changes to lighter shades of green deeper in the cores. The clay is mixed with terrigeneous input from the volcanic arc and its basement. The sediments are described in more detail in part 3 of this contribution [Kutterolf et al., 2008].

\subsection{Ash-Layer Correlation to Source Volcanoes}

[24] Correlations of marine ash beds to their parental tephras and source volcanoes on land are mainly based on glass chemical compositions and their statistical analysis (Figures 5 and 6) as the most distinctive characteristic but also consider modal, lithological and textural observations. Figures $6 \mathrm{a}-6 \mathrm{~h}$ show a compilation example of glass chemical variation diagrams (major elements, trace elements and ratios) that turned out most useful for the purpose of chemical correlation. Due to the large number of tephras and the wide range of differentiation grade separate panels showing characteristic regional subsets of the whole data; we give other diagram variations in auxiliary material Figure S1, and all correlations can also be seen in Table S2. These correlations are supported by results from cluster analyses (Figure 5) except for tephras from Central Nicaragua, for which this method yields some unreasonable stratigraphic relationships. Using the SPSS C version 14 software package we tested the significance of 42 elements and ratios by a factor analysis and identified 9 felsic principal components (Figure 5a) most 

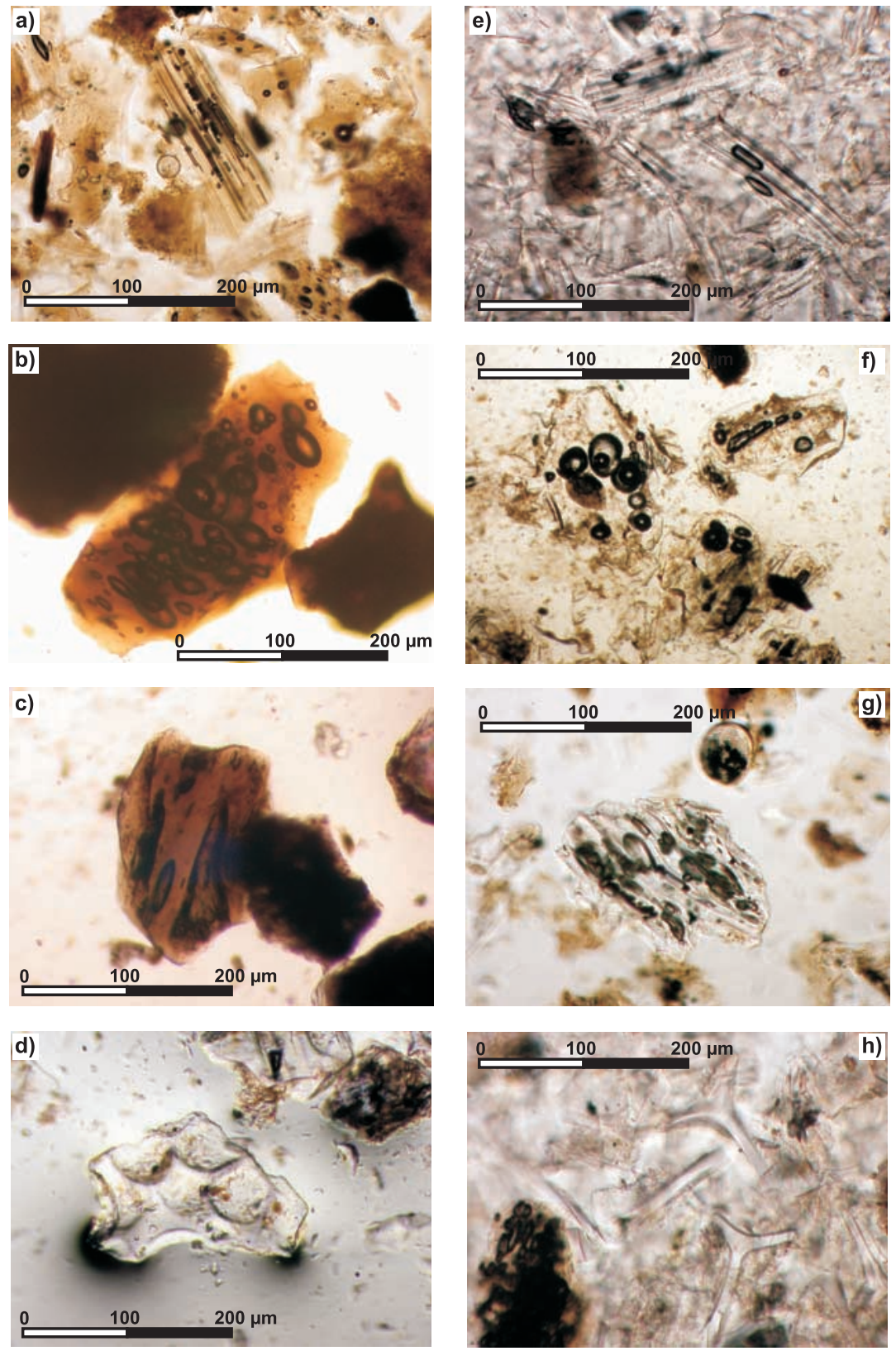

Figure 4. Smear-slide microphotographs showing glass-shard textures of $(a-c)$ mafic and $(d-h)$ silicic marine ash layers. (a) M66-222/517 cm bsf: mafic ash with tubular brown shards. (b) M66-222/436 cm bsf: round vesicles in sideromelane shard. (c) M66-222/436 cm bsf: elongated vesicles in sideromelane shard. (d) M66-226/78 cm bsf: silicic shard from highly vesicular pumice. (e) M66-226/47 cm bsf: fibrous shards from tube pumice. (f) M66-226/78 cm bsf: moderately vesicular felsic shards with round bubbles. (g) M66-222/51 cm bsf: pumice fragment with moderately elongated vesicles. (h) M66-222/96 cm bsf: y-shaped glass shards.

useful for cluster analysis. Hierarchical cluster analysis of those components then yielded the results shown in Figure 5b. Cluster analysis of felsic tephras successfully reproduces known stratigraphic relations. Mafic tephras are largely dominated by the major elements and only result in a rough grouping between Northern and Central
Nicaraguan Tephras. In summary, we have been able to correlate 129 marine ash horizons and literature data to 26 tephras onshore. Correlated marine ash layers in our cores are labeled $\mathrm{C} 1$ through C23 in stratigraphic order from young too old. The remaining 79 ash horizons have compositions not represented in our database; these occur 
a)

\begin{tabular}{|c|c|c|c|c|c|c|c|c|c|}
\hline \multirow{2}{*}{$\begin{array}{l}\text { Elementits } \\
\text { ratios }\end{array}$} & \multicolumn{9}{|c|}{ Principal Components } \\
\hline & & & & & & & & & \\
\hline & ,793 & -0,055 & .138 & ,200 & -044 & -288 &,- 245 & 091 & .082 \\
\hline 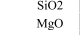 & 9.932 & $\begin{array}{llll}-0,74 \\
-, 045\end{array}$ & 0.056 & 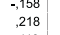 & . & . & $\begin{array}{llll}-, 106 \\
., 224\end{array}$ & . & $\begin{array}{llll}-0.022 \\
-., 026\end{array}$ \\
\hline & & & & & . & & $\begin{array}{l}.187 \\
187\end{array}$ & - & 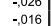 \\
\hline $\mathrm{Al2O} 3$ & 902 & . 189 & .013 & 191 & .013 & .200 & -006 & -0,01 &, 112 \\
\hline Tio2 & 8077 & .021 & 168 & -1117 & .052 & .097 & .303 & - -102 & -308 \\
\hline $\begin{array}{l}{ }^{2} 20 \\
c\end{array}$ & 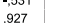 & . & 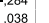 & . & . & 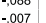 & $=$ & .068 0.068 & -,026 \\
\hline TAS & & 242 & 257 & $=-307$ & .875 & .075 & & .024 & 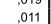 \\
\hline Mno & .768 & .023 & .050 & .427 & .280 & .163. & -068 & . 019 & .089 \\
\hline P205 & - & . 0400 & .320 & ,319 & .882 & 014 & . & 0.031 & .008 \\
\hline & 837 & 0.035 & 386 & ${ }_{150}$ & .024 & 145 & - & . & 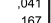 \\
\hline Y89 & .834 & .081 & .453 & . & .106 & .021 & .003 & -142 & .092 \\
\hline $\mathrm{Z} \mathrm{Z} \mathrm{9} 0$ & .736 & .434 & .202 & - & .172 & . 120 & - -071 & , & . \\
\hline $\begin{array}{l}\mathrm{Nb933} \\
\mathrm{C} 133 \mathrm{r}\end{array}$ & . 3862 & .502 & . & .117 & . 1.081 & . & . & . & -106 \\
\hline 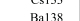 & & . & 655 & & 100 & 130 & $\begin{array}{l}-0866 \\
-0886\end{array}$ & 025 & 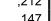 \\
\hline Lal39 & . 413 & 857 & 1.68 & -123 & .083 & 157 & .007 & 052 & -017 \\
\hline Cel40 & ,392 & 881 & .114 & ; 098 & 0,062 & . & .018. & , 070 &,- 068 \\
\hline Nol146 & & 6.684 & & & & & 0.058 & 0 & . \\
\hline Simlitif & 907 & 1.75 & 282 &, 177 & 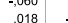 & 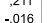 & $\begin{array}{l}.057 \\
.055\end{array}$ & $\begin{array}{l}0.003 \\
0.003\end{array}$ & ${ }_{1}, 005$ \\
\hline Galls8 & 881 & 250 & -237 & 072 & .064 & 249 & .063 & -045 & .0001 \\
\hline Dyl61 & 848 & , 151, & .373 & , & ; & 289 & , 0111. & . & \begin{tabular}{r|r}
-.025 \\
\end{tabular} \\
\hline $\begin{array}{l}\text { Erro67 } \\
\text { ret }\end{array}$ & .759 & 倠2 & ${ }_{4}^{403}$ & , & 127 & 2966 & .120 & 108 & - \\
\hline 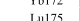 & & 120 & .451 & - & $\begin{array}{l}0.129 \\
0.999\end{array}$ & 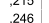 & - & .017 & 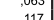 \\
\hline H1178 & .683 & .521 & . 062 & -393 & .123 & .112 & - & . 1488 & .101 \\
\hline Ta181 & .239 & 867 & . 339 & - -073 & , 134 & ,097 & - & .053 & . \\
\hline TT232 &,-2099 & 8966 & . 02020 & $=, 217$ & .0.066 & 0,060 &, 219 & .151 & -0.014 \\
\hline D.280 & 066 & 2 & -670 & $\begin{array}{l}-2,20 \\
-0.78\end{array}$ & 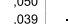 & $\begin{array}{l}2.273 \\
2009\end{array}$ & 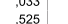 & $\begin{array}{l}., 1528 \\
3_{228}\end{array}$ & , 1800 \\
\hline $\mathrm{ZrNb}_{\mathrm{r}}$ & .475 & .626 & .294 & -411 & 178 & .024 & 219 & 101 & .094 \\
\hline Baztr &,- 616 & . & .436 & , 349 & ,071 & ,293 & 288 & - 1779 & 135, \\
\hline $\mathrm{La} / \mathrm{Y} \mathrm{b}$ & $\begin{array}{l}-.224 \\
.257\end{array}$ & . 7866 & . 4.377 & 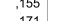 & 0866 & 118 & 169 & , 197 & 090 \\
\hline & & 288 & & & & & 065 & 021 & .0.064 \\
\hline cervb &,- 300 & 765 & ,400 & .194 & .055 & 145 & .173 & .223 & .035 \\
\hline Bala & .057 & ,774 & , 403, & |304. & .132 & .288 & , 078 & .095 & . 011 \\
\hline $\begin{array}{l}\text { CelEu } \\
\text { CecHF }\end{array}$ & . -5.599 & . 557 & .389 & . & . & . & . & .086 & . \\
\hline \multirow{2}{*}{ 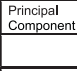 } & \multicolumn{4}{|c|}{ Initial eigenvalues } & \multicolumn{5}{|c|}{ Sum of squared factorial values for extraction } \\
\hline & total & variance & & nulative & total & & riance & oumy & unative \\
\hline & 17,810 & 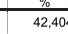 & & $\frac{76}{42,404}$ & 17,810 & & 42,404 & & \\
\hline${ }^{2}$ & 11,011 & 26,21 & & 68,620 & 11,011 & & 26,216 & & 68,620 \\
\hline & 4,119 & 9,80 & & 78,427 & 4,119 & & 9,806 & & 78,427 \\
\hline & 2,112 & 5,02 & & 83,454 & 2,112 & & 5,02 & & 83,454 \\
\hline & 1,915 & 4,55 & & 88,013 & 1,915 & & 4,559 & & \\
\hline & 1,196 & 2,84 & & 90,86 & 1,196 & & 2,847 & & \\
\hline & .968 & 2,30 & & 93,165 & 968 & & 2,305 & & \\
\hline . & ,571 & 1,36 & & 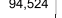 & .571 & & 1,360 & & \\
\hline & ,401 & .95 & & 95,479 & , 401 & & .995 & & 95,479 \\
\hline
\end{tabular}

b) Hierarchical Cluster Analysis FELSIC Tephras

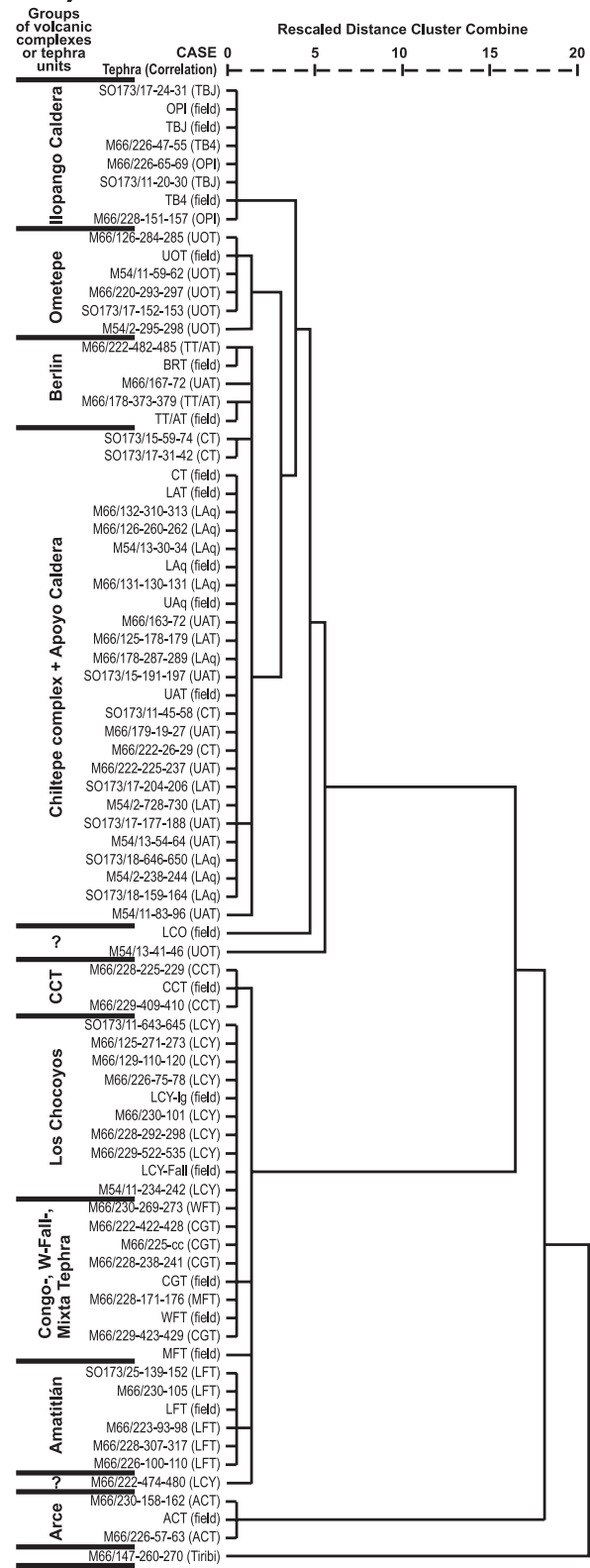

Figure 5. (a) Results of factor analysis used to reduce 42 elements and element ratios to 9 principal components which account for $95 \%$ of variance in the samples and are most useful for cluster analysis. (b) Dendrogram of hierarchical cluster analysis (squared Euclidean distance, farthest neighbor method) using reduced components from factor analysis. The cluster analysis successfully reproduces known stratigraphic relations except for tephras from Central Nicaragua for which the chemical differences are too small.

deeper in the cores and relate to older onshore stratigraphic units. We discuss the successful correlations according to the source volcanic centers in geographic order from north to south.

\subsubsection{Atitlán Caldera}

[25] The pyroclastic sequence at Atitlán Caldera formed during at least three major caldera-forming events [Rose et al., 1987]. From bottom to top, the succession of the past $200 \mathrm{ka}$ comprises the W-fall and flow tephra, Los Chocoyos $\mathrm{H}$-fall and flow tephra, D-fall deposits, F-fall deposits, and I-fall deposits [Rose et al., 1987] (Figure 1). Ash layer C22 in core M66-230, comprising a 4-cm-thick primary ash layer $(269-273 \mathrm{~cm} \mathrm{bsf})$ and a reworked ash pod $(228-232 \mathrm{~cm}$ bsf) correlates 

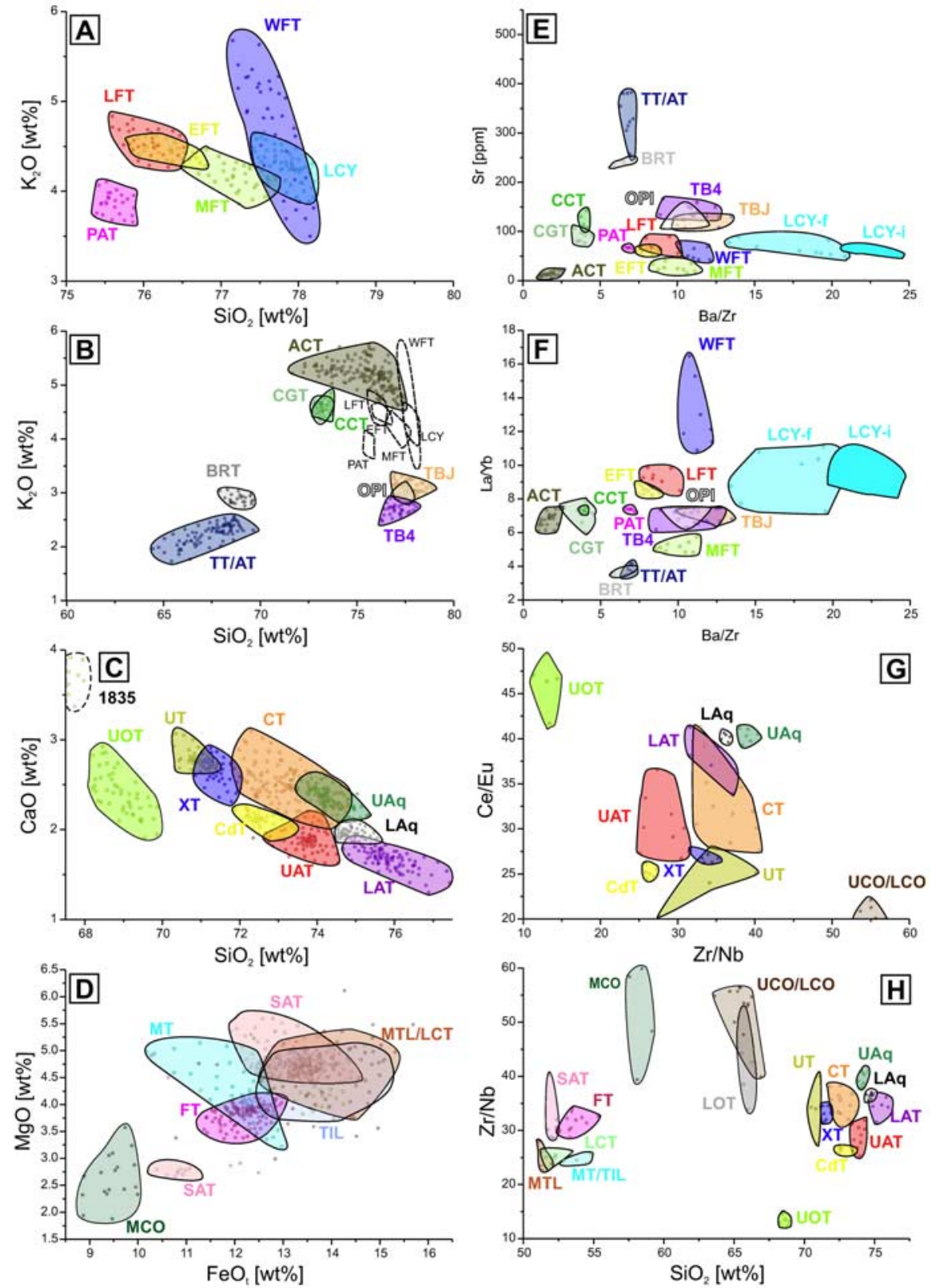

Figure 6. Matrix-glass compositional ranges of pumice lapilli from onshore tephras (normalized to anhydrous compositions). One-sigma analytical precision is better than $2 \%$ for the major elements (Figures $6 \mathrm{a}-6 \mathrm{~d}$ ) and 10\% for the trace elements (Figures 6e-6h). (a) Guatemalan tephras, (b) tephras of El Salvador, (c) Nicaraguan felsic tephras, (d) Nicaraguan mafic tephras, (e and f) trace elements and ratios tephras of Guatemala and El Salvador, (g) trace elements felsic Nicaraguan tephras, and (h) trace elements, all Nicaraguan tephras. Tephra acronyms are given in Figure 1. Dotted fields mark tephras from Guatemala. Additional diagrams are given in Figures S1a-S1p.

with the W-tephra (WFT) (Figures 7 and 8 and Tables 1 and S2), although it is in the same cluster group as Los Chocoyos Tephra. The nearby core RC-12-32 of Bowles et al. [1973] contains an ash layer at $242 \mathrm{~cm}$ bsf, which corresponds to our C22 and the WFT. Bowles et al. [1973] provide bulk chemical compositions of manually separated vitric ash that should be comparable (although with caution) to our glass compositional data. The WFT has a high crystal content in the ash (up to $50 \%$ ), a mafic basal fall layer (which we did not recognize in the submarine layer $\mathrm{C} 22$ ), white juvenile pumice clasts with medium phenocryst contents $(10-15 \%)$ comprising quartz $(q z)$, plagioclase $(p l)$, biotite $(b i)$ and minor pyroxene $(p x)$, amphibole $(\mathrm{am})$ and magnetite $(\mathrm{mt})$ [Rose et al., 

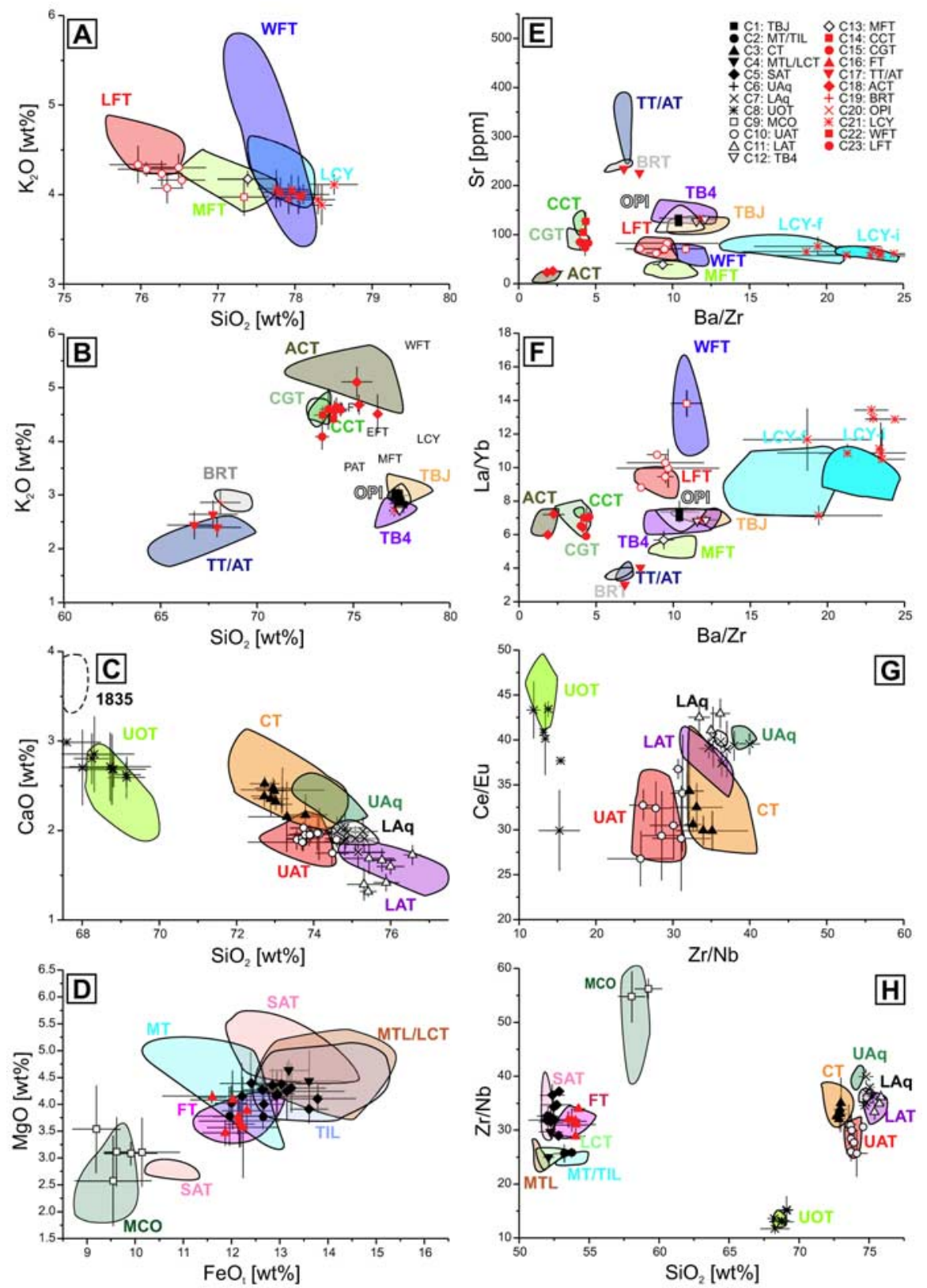

Figure 7. Glass shard compositions of marine ash layers compared with glass-composition fields of tephras on land. See Figure 1 for tephra acronyms. Data are averages of all analyses made for each tephra. Symbols in top right corner identify C-layers shown in Figure 8. Additional diagrams are given in Figures S1q-S1af.

1987]. The mineral assemblage in our marine ash layer $\mathrm{C} 21$ contains abundant crystals $(>5 \%)$ of $\mathrm{pl}$, $b i, q z$ and minor am, which is consistent with the onshore tephra.

[26] Ash layer C21 occurs in cores M66-125, 129, 222, 226, 228, 229, 230; M54-11; SO173-11, 13, 15 , and 25 as a distinct bed or as lenses of ash (Figures 7 and 8 and Tables 1 and S2). Layer C21 correlates with the widespread Los Chocoyos tephra (LCY) that was also recognized in numerous other cores by Bowles et al. [1973] and Ledbetter [1985]. Our data support Ledbetter's proposed correlation of his D-Layer to the Los Chocoyos eruption (Figure 1 and Tables 1 and S2). The LCY on land is characterized by conspicuous highly elongated tubular white pumice clasts and corresponding shard shapes are observed in every chemically correlated marine ash. Phenocrysts of the crystalpoor pumice are abundant $p l, q z$, to a lesser amount $b i$ and traces of am, which is consistent to the mineral assemblage and the order of abundance 


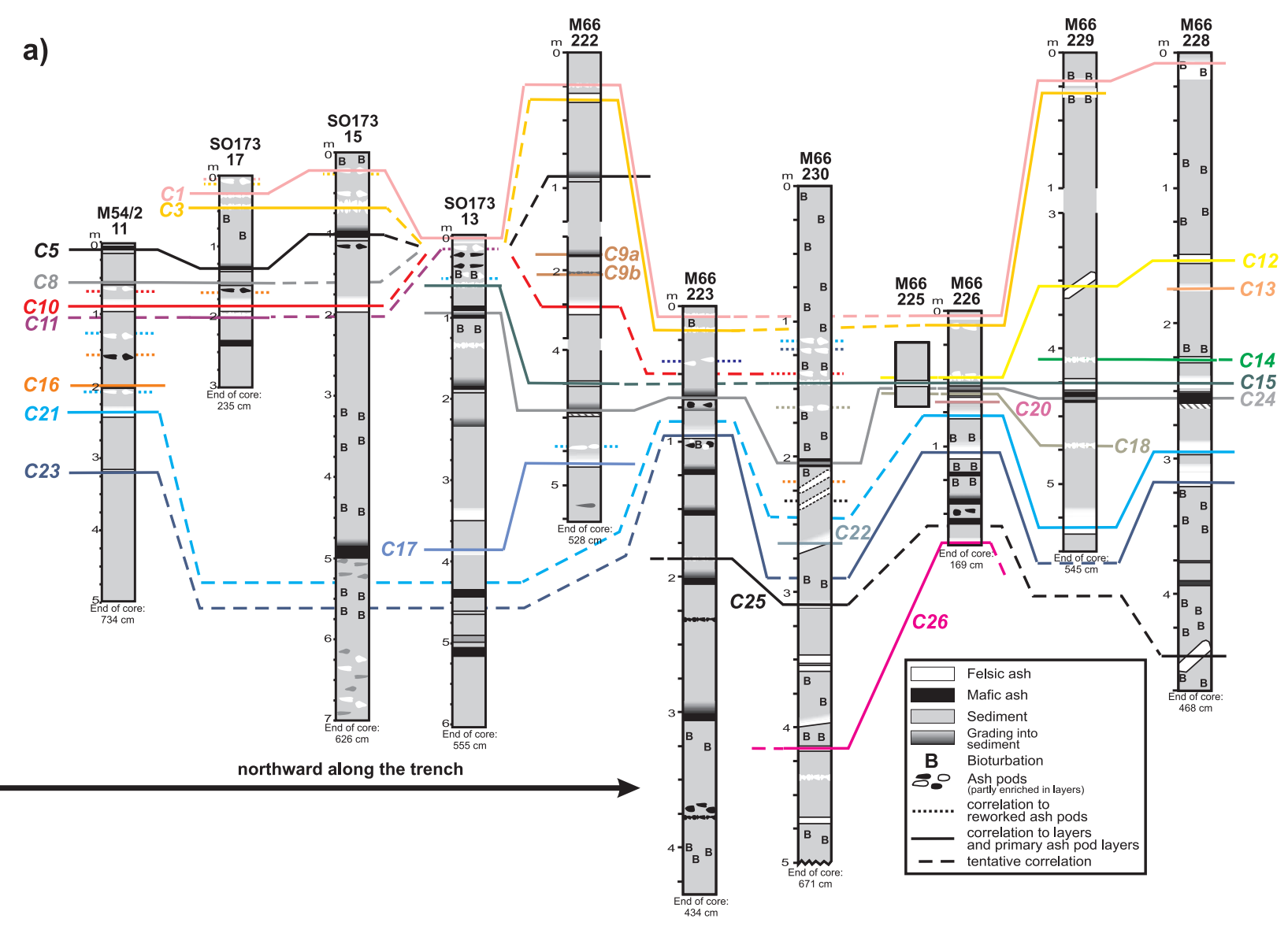

Figure 8. (a) Compositionally correlated ash layers $\mathrm{C} 1$ through $\mathrm{C} 26$ provide stratigraphic links between the eleven selected cores from the incoming plate arranged from S (left) to N (right). Breaks in cores 222 and 229 are thick intervals of monotonous pelagic sediment that were omitted. Layers C1 to C23 correlate with tephras on land as shown in Figure 7. Unlabeled ash layers could not be correlated. (b) Compositionally correlated ash layers C1 through $\mathrm{C} 17$ provide stratigraphic links between the selected four cores at the continental slope, and with those on the incoming plate (Figure 8a).

we found in the marine ashes $(<2 \%$ crystals $)$. Toward larger distances (offshore Nicaragua) crystal concentration decreases and $b i$ and $p l$ dominate the mineral assemblage. Glass texture and the low crystal content rule out correlations with marine tephras that are in the same cluster-group.

\subsubsection{Amatitlán Caldera}

[27] Koch and McLean [1975], Wundermann [1982] and Wundermann and Rose [1984] identified six tephra units originating from Amatitlán Caldera; from bottom to top these are L-flow and fall, Z-falls, T-flow and fall, C-fall, E-fall and J-falls. All these tephras have similar mineral assemblages consisting of dominant $p l$ with $a m, b i$, Fe-Ti oxides, $p x$ and occasional traces of $q z$. Ash layer $\mathrm{C} 23$ in cores M66-223, 226, 228, 230; M54-11 and SO17325 can be correlated with the L-tephra (LFT) (Figures 7 and 8 and Tables 1 and S2) and is always the oldest tephra that can be correlated to sources from land; it builds a separate cluster group in statistical analysis. Moreover, we identified corresponding ash layers using documented compositional data, in DSDP Leg 67 (Figure 1 and Tables 1 and S2) as well as in the cores of Bowles et al. [1973]. The $191 \pm 11 \mathrm{ka}$ old LFT on land [Rose et al., 1999] contains light brownish gray to white pumice clasts with $\mathrm{pl}$, am and bi phenocrysts (in order of abundance). The mineral assemblage in our marine ash layer C23 contains abundant crystals (3-5\%; decreasing in distance) of predominantly $p l$, abundant $b i$, and traces of $a m$. The glass shards are characteristically highly vesicular and mostly of elongated texture.

[28] The E-tephra (EFT) is a coarse grained reversely graded fall of white pumice clasts distributedacross an area of $\sim 1300 \mathrm{~km}^{2}$ on land [Wundermann, 1982; Wundermann and Rose, 1984]. It has a high 
b)

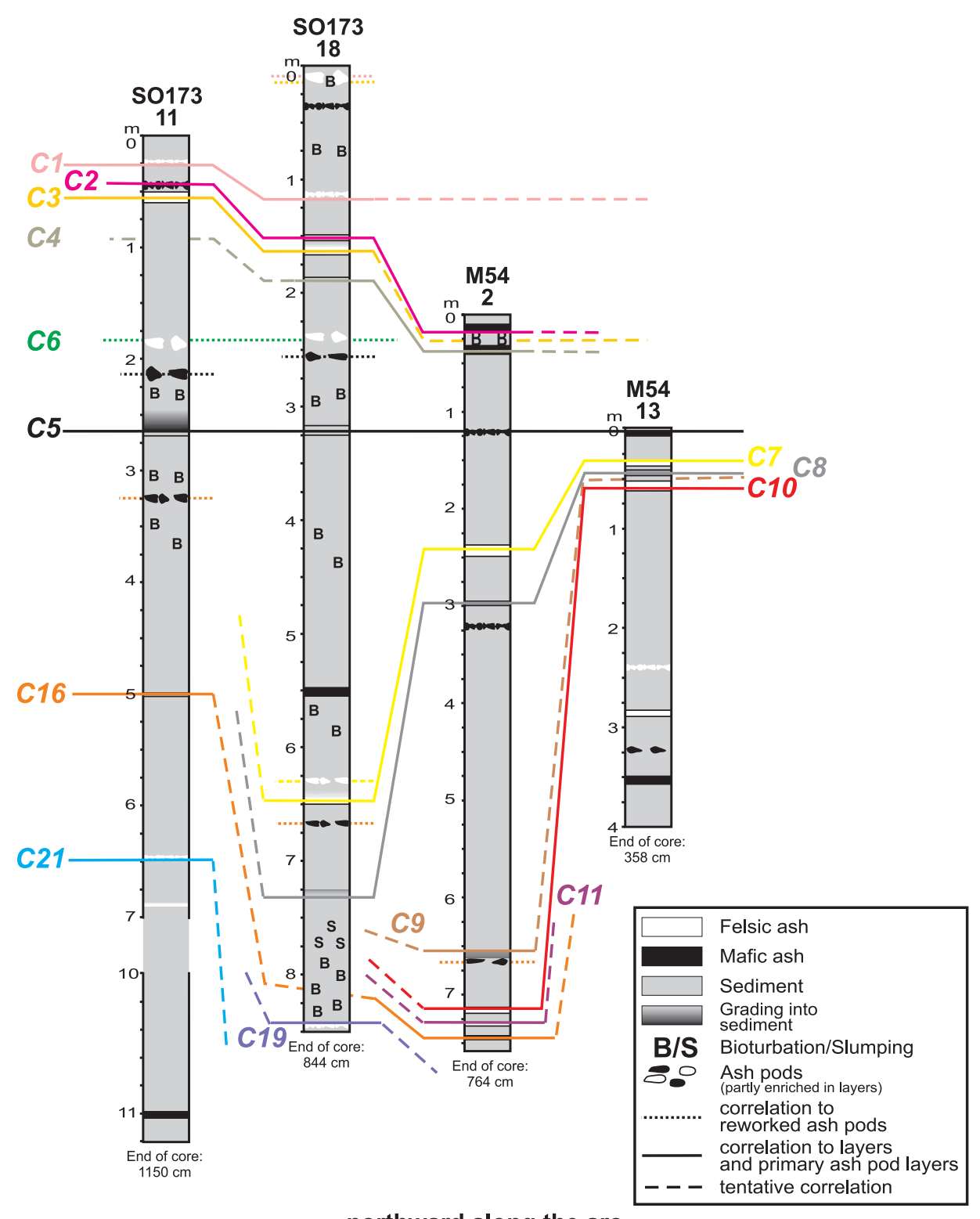

northward along the arc

Figure 8. (continued)

crystal content $(10-15 \%)$ that is dominated by increasing bi-content toward the top. We did not find the EFT in our cores but observe possible correlations based on published data. Compositions of an ash layer at DSDP Leg 84 (570-2-3) and of the D3 ash layer of Bowles et al. [1973] correspond to EFT glass compositions (Tables 1 and S2). Excellent compositional agreement is also found for the Y5 ash layer in the Gulf of Mexico (Tables 1 and S2) documented by Rabek et al. [1985].

\subsubsection{Ayarza Caldera}

[29] Ayarza Caldera in the south of Guatemala consists of two nested calderas that produced the $27 \pm 1.6$ ka old Mixta Tephra, the Pinos Altos Tephra, and the younger $(23 \pm 0.5 \mathrm{ka})$ Tapalapa Tephra [Peterson and Rose, 1985] (Figure 1). The Mixta Tephra (MFT) is a compositionally zoned tephra with pale brown to black and banded pumice clasts. It is a phenocryst-poor deposit with $p l$ and $b i$ in the rhyolitic and $a m$ in the basaltic endmembers [Peterson and Rose, 1985]. Glass shards 


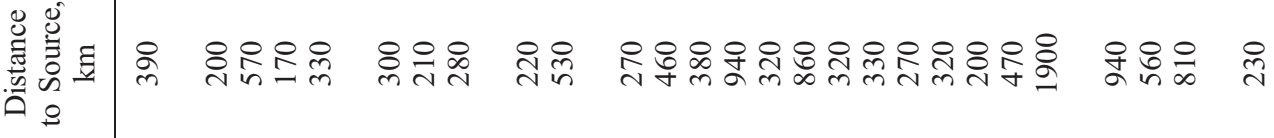

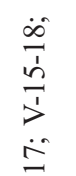

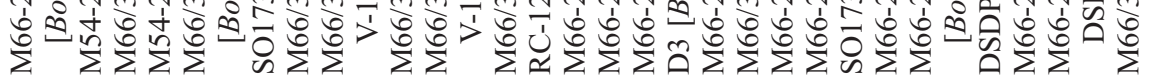

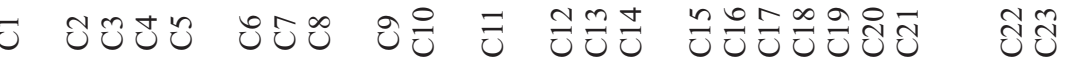

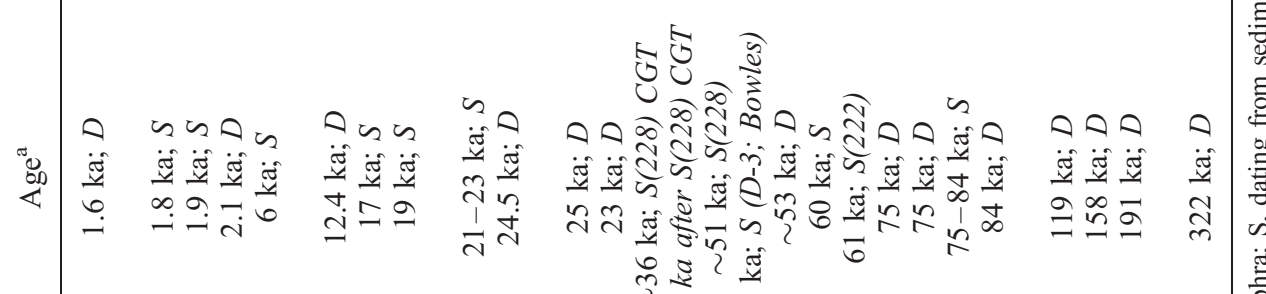

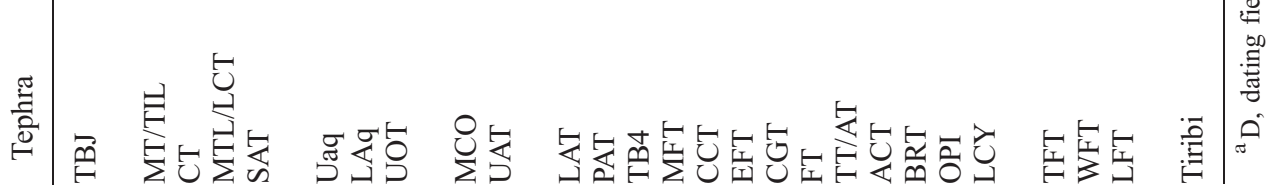


of ash layer C13 in our core M66-228 (171-176 cm bsf) have the composition of the rhyolitic MFT glass (Figures 7 and 8 and Tables 1 and S2); we found only a small amount of the basaltic Mixta component in the distal ash beds suggesting only the early rhyolitic eruption phase was sufficiently intense for such wide dispersal. The low crystal fraction in layer $\mathrm{C} 13$ contains predominantly $\mathrm{pl}, \mathrm{bi}$, and minor am. Glass shards are mostly colorless and elongated but only moderately vesicular, with some brownish glass shards admixed. The glass composition data of the C-layer of Bowles et al. [1973] reported by Drexler et al. [1980] fit our correlation field of the MFT. Moreover, glass composition data from DSDP Leg 84 (570-2-1/ 141) of an ash layer at $621 \mathrm{~cm}$ bsf also corresponds to the MFT composition (Tables 1 and S2).

[30] The Pinos Altos Tephra (PAT), a thick pumice fall deposit, rests on a meter-thick paleosol [Peterson and Rose, 1985] and is overlain by the Tapalapa Tephra, locally separated by an erosional unconformity. The PAT white rhyolitic pumice is crystal-poor with $p l, b i$ and am phenocrysts. A similar phenocryst assemblage but with more $b i$ and less am is found in the Tapalapa pumice. The Tapalapa Tephra is a very ash-rich deposit probably formed by a phreatomagmatic eruption [Peterson and Rose, 1985]. Our trace element data confirm the correlation of Peterson and Rose [1985] with an ash layer $50 \mathrm{~cm}$ bsf in core RC12-32 of Bowles et al. [1973] (Tables 1 and S2). However, we did not find Pinos Altos or Tapalapa tephras in our cores.

\subsubsection{Coatepeque Caldera}

[31] Silicic activity at Coatepeque Caldera in northern El Salvador (Figure 1) began with the Bellavista eruption at $77 \pm 2 \mathrm{ka}$ [Rose et al., 1999]. Coatepeque activity continued to produce the $72 \pm$ 3 ka old Arce Tephra, followed by the Congo Tephra (53 $\pm 3 \mathrm{ka}$; own radiocarbon dating) and the recently identified Conacaste Tephra (C. Pullinger, SNET, personal communication, 2005). The largest deposit of the three is the Arce Tephra (ACT), which includes plinian fall beds and ignimbrite. Its highly vesicular pumice contains a high amount of $b i$, abundant $p l$, and minor $p x$ phenocrysts. Glass compositions of ash layer C18 in cores M66-226, 229, and 230 are in the same cluster-group as the ACT (Figures 7 and 8 and Tables 1 and S2) and this correlation is supported by petrographic and stratigraphic characteristics. The mineral assemblage in layer $\mathrm{C} 18$ contains a high amount of crystals $(5-7 \%)$ predominantly of $b i(\sim 5 \%)$, some $p l$, and minor $p x$, which is con- sistent with the Arce pumice phenocryst assemblage. The marine ash is mostly a mixture of strongly elongated glass shards and highly vesicular pumice fragments. Compositional data indicate that ash beds sampled in the Caribbean by Rabek et al. [1985] (K131-446 cm bsf; TR126-22 $321 \mathrm{~cm}$ bsf) may be distal ACT but we presently cannot validate this correlation with certainty.

[32] The Congo Tephra (CGT), which we traced up to Guatemala City, is a complex succession of plinian fall, ignimbrite and surge deposits with highly vesicular pumice containing $p l, p x$ and $a m$ phenocrysts as well as olivine xenocrysts. We chemically correlate ash layer C15 in cores M66$222,225,228,229,230$ and SO173-13 with the CGT (Figures 7 and 8 and Tables 1 and S2), although it is in the same cluster group as LCY and WFT. The shape of the glass shards in ash layer C15 is mostly angular and cuspate. The moderate crystal content $(3-5 \%)$ comprises $p l>$ $a m>p x$ and, in more proximal marine ashes, also olivine $(o l)$. Moreover, the glass composition of an ash layer at DSDP Leg 84 [Pouclet et al., 1985] fits the CGT glass composition (Tables 1 and S2).

[33] The Conacaste Tephra (CCT) comprises a lower fall section of two pumice lapilli beds bracketing a central fine ash fall extremely rich in accretionary lapilli, and an upper surge package; we interpret this as the product of a phreatoplinian eruption. The highly vesicular white pumice contains $p l, p x$ and am phenocrysts and also olxenocrysts. Glass shards of ash layer $\mathrm{C} 14$ in cores M66-228 and 229 have the glass composition of Conacaste pumice (Figures 7 and 8 and Tables 1 and S2) and a higher amount of elongated and vesicular types compared to layer C15. However, since glass compositions and mineral assemblages of the Congo (C15) and Conacaste (C14) tephras are identical, correlations to both tephras rely on stratigraphic order, and on successful multielement discrimination by the cluster analysis.

\subsubsection{Ilopango Caldera}

[34] The Ilopango caldera in central El Salvador produced at least five tephra deposits (Figure 1) since the Upper Pleistocene. From youngest to oldest, these are the Tierra Blanca Joven (TBJ) and the TB2, TB3 and TB4 tephras [Rose et al., 1999]. There are also remains of a deposit from an older eruption at the shore of the caldera lake [Mann et al., 2004]. The TBJ has been radiocarbon dated at A.D. $429 \pm 107$ [Dull et al., 2001] and comprises a succession of fall, ignimbrite and surge 
deposits [Hart and Steen-McIntyre, 1983]. The TBJ is interpreted as the product of a complex phreatoplinian eruption [Houghton et al., 2000]. The white to pinkish TBJ pumice contains abundant $p l$, am and $p x$ phenocrysts, an assemblage that is also typical for the TB2-TB4 tephras of Ilopango Caldera. The TBJ Tephra occurs as layer C1 in the upper few decimeters of many of our Pacific sediment cores from Guatemala to Nicaragua and we also recognized it in the core data of Bowles et al. [1973] (Figures 7 and 8 and Tables 1 and S2). The sequence of Ilopango tephras clusters in one group of the statistical analysis but our correlation of layer $\mathrm{C} 1$, which is commonly represented by ash pods rather than by distinct primary ash layers, with the TBJ is supported by stratigraphic position, shallow depth below seafloor and the moderate mineral content $(3-5 \%)$ with $p l>a m>p x$ decreasing toward distal locations.

[35] The TB4 Tephra (C12) is a yet undated, prominent white massive pumice lapilli fall deposit that can be traced a long distance to the northwest where it overlies the Congo Tephra [Rose et al., 1999] and hence must be younger than $53 \mathrm{ka}$. The pumice contains a low amount of phenocrysts with $p l$ as the dominant phase and minor $a m$ and $p x$. We identified layer C12 in cores M66-226, 228, and 229 as the distal equivalent of TB4 on the basis of glass composition (Figures 7 and 8 and Tables 1 and S2), stratigraphic order and low crystal content $(<2 \% ; p l \gg a m>p x)$. Distal TB4 ash apparently also occurred at DSDP Leg 67 (Tables 1 and S2).

[36] We also found an ash layer in core M66-226 (65-69 bsf) with a glass composition very similar to that of the older pumice deposit inside Ilopango Caldera described by Mann et al. [2004] (Figures 7 and 8 and Tables 1 and S2). This ash layer occurs between those of the Arce and Los Chocoyos tephras, bracketing its age to between 73 and $84 \mathrm{ka}$, and also clusters into the group of Ilopango tephras in the statistical analysis.

\subsubsection{Berlin-Pacayal-Volcan Group}

[37] A stratigraphic study of the volcanic deposits from this group of volcanoes in southern El Salvador by Nairn and coworkers of DSIR, New Zealand, is documented in an internal report [CEL, 1995]. They identified six major tephras which are from old to young: the Blanca Rosa Tephra (75 $\pm 10 \mathrm{ka})$, Twins/A-Tephra, Pacayal-1 Tephra, Volcan Tephra and Pacayal-3 Tephra (Figure 1). Of these we recognized the Twins/ATephra (TT/AT) and possibly the Blanca Rosa
Tephra (BRT) in the marine cores. The TT/AT have been described as three separate units but our reinvestigation did not reveal any indication of a significant time break between the formation of these three layers which are also identical in major and trace element compositions of bulk pumice and matrix glass. We therefore interpret the three layers as the deposits of one eruption producing three thick fall lapilli beds as well as a pyroclastic flow deposit. Pumice lapilli vary in color (dark gray, pale brown, reddish, banded) and composition but all contain high amounts of $p l>p x$ phenocrysts. Layer C17 in cores M66-222, 178 and 131 correlates with the TT/AT in terms of major and trace element glass compositions as well as relative stratigraphic position (Figures 7 and 8 and Tables 1 and S2). The correlation is supported by the abundance of colorless and pale brown, moderately vesicular glass shards with $p l$ phenocrysts and the relatively high crystal content $(5-7 \%)$ of the ash dominated by $p l$ with a minor amount of $p x$.

[38] Major element glass compositions suggest that an ash layer in core SO173-18 may correlate with the BRT (Figure 8 and Tables 1 and S2). Trace element analyses will have to validate this correlation, since the mineral assemblage is similar to the TT/AT.

\subsubsection{Cosigüina Caldera}

[39] Cosigüina peninsula at the Gulf of Fonseca is the northernmost volcano of Nicaragua. Products of its last plinian eruption in A.D. 1835 have been studied by Williams [1952], Self et al. [1989], and, recently, Scott et al. [2006], who also observed mafic and felsic fall deposits of older, undated eruptions of this volcano. Of these older deposits, we sampled the uppermost mafic, crystal rich (15$20 \% ; p l \gg p x)$ scoria fall tephra from a set of three (MCO1 to MCO3) in a canyon north of Punta Nata, and two overlying dacitic pumice falls, the Lower and Upper Cosigüina tephras (LCO and UCO). Although the thick LCO and UCO appear to be widespread plinian deposits, only the thinner MCO1-tephra can be correlated to marine tephras since it has a uniform chemical composition. Ash layer C9 in core M54-2 (661-662 cm bsf) and reworked ash pods in nearby core SO173-52 as well as M66-174 correlate compositionally with the MCO tephra (Figures 7 and 8 and Tables 1 and S2). In addition, this tephra corresponds very well to ash layers C9a but also nearly to $\mathrm{C} 9 \mathrm{~b}$ in core M66-222 offshore El Salvador suggesting that C9b is one of the older $\mathrm{MCO}$ tephras (MCO2 to MCO3). The crystal fraction of ash layer C9/a + 
b contains abundant $(5-10 \%) p l \gg p x$, consistent with the onshore tephras, but a distinction between MCO1-3 is not possible. Using documented compositional data, we also find correlations with ash layers in cores V-15-26 (510 and $539 \mathrm{~cm} \mathrm{bsf}$ ) and V-15-22 (112 cm bsf) of Bowles et al. [1973] (Tables 1 and S2), which were taken close to Cosigüina volcano. In cores V-15-26 and M66-222, the MCO ash occurs above the distal ash of the Upper Apoyo Tephra and hence must be younger than $25 \mathrm{ka}$.

\subsubsection{Chiltepe Volcanic Complex}

[40] The Chiltepe peninsula at the western shore of Lake Managua is a volcanic complex including the central Apoyeque stratocone, the Xiloa maar, at least two more, now hidden, vents of plinian eruptions and several basaltic cinder cones and maars [Freundt et al., 2006a, 2006b; Kutterolf et al., 2007a]. During the past $15 \mathrm{ka}$, this volcanic complex erupted six dacitic tephras of plinian dispersal: the hornblende bearing Lower and Upper Apoyeque $(12.4 \mathrm{ka})$ tephras, the $6.1 \mathrm{ka}$ Xiloa Tephra, the Mateare and Los Cedros tephras, and finally the olivine bearing, crystal-rich Chiltepe Tephra $<2$ ka ago. Glass compositions identify ash layer C3 in cores M66-222, 223, 226, 229; SO173-11, 18, 15, and 17 (Figures 7 and 8 and Tables 1 and S2), and an ash layer $75 \mathrm{~cm}$ bsf in core V-15-26 of Bowles et al. [1973] as distal equivalents of the Chiltepe Tephra (CT). Since the cluster analysis of Central Nicaraguan Tephras does not yield satisfactory solutions, these correlations are mainly based on the correlation plots, the stratigraphic positions in the cores, glass shard textures and the mineralogy $(3-5 \% ; p l>p x>o l)$ of the ash layers. The occurrence of olivine crystals and the characteristic highly vesicular, pumice fragment-rich ash horizons together with the fact that this is one of the youngest tephras in this area facilitate the correlation to the CT.

[41] The $12.4 \mathrm{ka}$ Upper Apoyeque Tephra (UAq) is a coarse grained, reversely graded pumice fall containing characteristic high amounts of hornblende. We did not find the UAq as a primary ash layer in our cores but as reworked ash pods (C6 in Figure 8b) in cores SO173-11 and 18 (Figure 7 and Tables 1 and S2). It also probably correlates with a $>1-\mathrm{cm}-$ thick ash layer $580 \mathrm{~cm}$ bsf in core V-15-26 of Bowles et al. [1973] (Tables 1 and S2). Marine ash layer C6 contains abundant crystals (5-7\%) with am clearly dominating the assemblage with minor $p l$ and $p x$. The high am content is the only way to distinguish
Upper from Lower Apoyeque ash because both have the same glass composition.

[42] The Lower Apoyeque Tephra (LAq), which is poorly exposed on land since it was emplaced during the terminal phase of a period of intense erosion, compositionally corresponds to ash layer C7 in cores M54-2, 13 and SO173-18, 98 as well as M66-178, 174, 152, 132, 131 and 126 (Figures 7 and 8 and Tables 1 and S2). The mineral assemblage in layer $\mathrm{C} 7$ contains $p l>p x>a m$ at moderate crystal contents $(3-5 \%)$ which is consistent to the onshore tephra. Due to compositional similarity, the assignment of C6 to UAq and C7 to LAq is largely based on stratigraphic order and the bracketing of both by overlying and underlying other known tephras.

\subsubsection{Masaya Caldera}

[43] The Masaya Caldera is a basaltic volcano that has produced large-magnitude plinian and phreatomagmatic eruptions [Bice, 1980, 1985; Williams, 1983]. The oldest known is the Fontana Tephra (FT), which is a mafic plinian fall that erupted from a vent northwest of the Masaya Caldera [Wehrmann et al., 2006]. Vents within Masaya Caldera erupted the plinian to phreatomagmatic San Antonio Tephra (SAT, <6 ka), the Masaya Triple Layer (MTL, $2.1 \mathrm{ka})$ and La Concepción Tephra (LCT), both of plinian dispersal and representing different northern and southern facies of a single eruption product, and finally the Masaya Tuff (MT) that resulted from a huge surtseyan eruption $<2 \mathrm{ka}$ ago that concluded with another plinian scoria fall, the Ticuantepe Lapilli (TIL) [Pérez and Freundt, 2006]. The mafic tephras have overlapping major-element glass compositions and very similar modal compositions (3-5\% minerals; $p l>p x>o l)$; trace element compositions and further differentiation possible by stratigraphic position and the depth below seafloor are thus essential for the correlation of mafic marine ash layers with these tephras (Figure 8).

[44] Marine ash layer $\mathrm{C} 2$ occurs in three cores at the Nicaraguan continental slope (SO-11, 18, and M54-2) and can be correlated to the MT/TIL by glass composition, relative stratigraphic position and high amount of tachylitic particles (Figures 7 and 8 and Tables 1 and S2).

[45] Only cores M54-2 and SO173-18 contain a mafic ash layer (C4) that correlates to the MTL/ LCT plinian deposit (Figures 7 and 8 and Tables 1 and S2) underlying the CT tephra (layer C2).

[46] The SAT is a sequence of black scoria falls overlain by surge deposits; the plinian fall can be 
traced on land to distal exposures north, northwest and south of the Masaya Caldera [Pérez and Freundt, 2006]. Geochemical fingerprinting shows that marine ash layer C5 in cores SO173-11, 15, 17, 18, M54-11, 13, M66-178, 167, 151 and M66-222 is equivalent to the SAT (Figures 7 and 8 and Tables 1 and S2). Additional criteria are the low crystal content and high amount of sideromelane shards with elongated vesicles. It also probably correlates with a $>1$-cm-thick ash layer $270 \mathrm{~cm}$ bsf in core V-15-26 of Bowles et al. [1973] (Tables 1 and S2). The SAT is thus the most widely traced of the Masaya tephras.

[47] The Fontana Tephra is a layered sequence of dark-gray, highly vesicular scoria lapilli fall beds that have a wide, plinian dispersal toward the NW of Masaya Caldera [Wehrmann et al., 2006]. This mafic tephra compositionally corresponds to ash layer C16 in cores M54-2 and 11; SO173-11, 13, 15, 17, 18, and 39, as well as M66-162 (Figures 7 and 8 and Tables 1 and S2). The deeper stratigraphic position in the cores and much higher sideromelane/tachylite ratio distinguish it from the compositionally similar MT/TIL.

\subsubsection{Apoyo Caldera}

[48] Apoyo Caldera, $35 \mathrm{~km}$ southeast of Managua, generated two large plinian eruptions in rapid succession $24.5 \mathrm{ka}$ ago, which produced the rhyodacitic Lower (LAT) and Upper (UAT) Apoyo Tephras that are separated by an incipient paleosol [Freundt et al., 2006a; Kutterolf et al., 2007a]. Glass compositions (Figure 7) and mineral contents differ since LAT contains also $o l$-xenocrysts in addition to $p l$ and $p x$. We correlate the UAT with ash layer $\mathrm{C} 10$ in cores M54-2, 11, 13, SO173-15, 17, M66-222, 179, 178, 174, 167, 163, and 131 (Figures 7 and 8 and Tables 1 and S2) as well as with ash beds in cores V-15-27, 18, 22 and 26 of Bowles et al. [1973]. Layer C10 contains $3-5 \%$ crystals with $p l>p x$ but no ol. This makes the UAT the most widely recognized tephra offshore Nicaragua.

[49] Ash layer C11 in cores M54-2, M66-178, 163, 125, 118 and SO173-13 and 17 has the more evolved glass composition of the LAT, contains $o l$ next to $p l$ and $p x$ crystals, and occurs at the correct position immediately below the UAT layer C10 (Figures 7 and 8 and Tables 1 and S2).

\subsubsection{Concepción Volcano}

[50] Concepción stratocone rises 1,600 m on Ometepe island in Lake Nicaragua and produced basaltic to dacitic pyroclastic successions [Borgia and van Wyk de Vries, 2003] which we group as the Ometepe Formation. This includes the prominent dacitic Tierra Blanca 3 Tephra, erupted $2720 \pm$ 60 BP [Borgia and van Wyk de Vries, 2003]. We studied two dacitic, $p l$, am and $p x$ bearing (phenocryst content 1-5\%), 1-2 $\mathrm{m}$ thick pumice fall deposits, which we term the Upper and Lower Ometepe Tephras (UOT and LOT), separated by a paleosol at three outcrops across the southwestern part of Ometepe island. We extend our earlier correlation of UOT with ash beds offshore Nicaragua [Kutterolf et al., 2007b] to other cores and support it by trace element data. The UOT correlates with ash layer C8 in cores M54-2, 11 and 13 as well as SO173-17, 18, M66-220, 174, 163, and 126 and with ash beds in cores V-15-18, 27 and 19 of Bowles et al. [1973] (Figures 7 and 8 and Tables 1 and S2). Layer C 8 contains $1-3 \%$ crystals of $p l>a m>p x$ and clusters in the same group with the Ometepe rocks. It is bracketed by the LAq and UAT and thus formed between $\sim 15$ and $25 \mathrm{ka}$ ago. It is therefore significantly older than the Tierra Blanca 3 Tephra of Borgia and van Wyk de Vries [2003].

\subsubsection{Tephras From Costa Rican Volcanoes}

[51] The unique trachytic composition, and characteristic trace element concentrations (e.g., high $\sim 700 \mathrm{ppm} \mathrm{Zr}$ ) make it easy to correlate the $322 \mathrm{ka}$ Tiribi Tuff [Pérez et al., 2006] with marine ash beds. We find the distal ash of the Tiribi Tuff in core M66-147 (260-270 cm bsf) and also as the I6-Layer of Ledbetter [1985] (Tables 1 and S2).

\subsubsection{Tephras From Unknown Sources}

[52] 82 felsic and mafic tephras in the cores offshore Central America cannot presently be correlated with individual tephras, although some can be correlated between cores (e.g., C24, C25 and C26; Figure 8). Some relatively potassium-rich ashes, however, do not fit CAVA compositions. We speculate that these were derived from Mexican volcanoes. Further constraints on the source regions for these ash layers can be derived from comparison with the systematic along-arc variation of trace element characteristics of the arc rocks [e.g., Carr et al., 2003, 2007; Carr, 1984; Feigenson and Carr, 1986; Feigenson et al., 2004; Hoernle et al., 2002; Patino et al., 1997, 2000]. The along-arc variations of $\mathrm{Zr} / \mathrm{Nb}, \mathrm{Ba} / \mathrm{La}$ and $\mathrm{Ce} / \mathrm{Yb}$ are roughly symmetrical such that these parameters do not efficiently distinguish between Guatemalan and Costa Rican compositions (Figure 9). Considering 


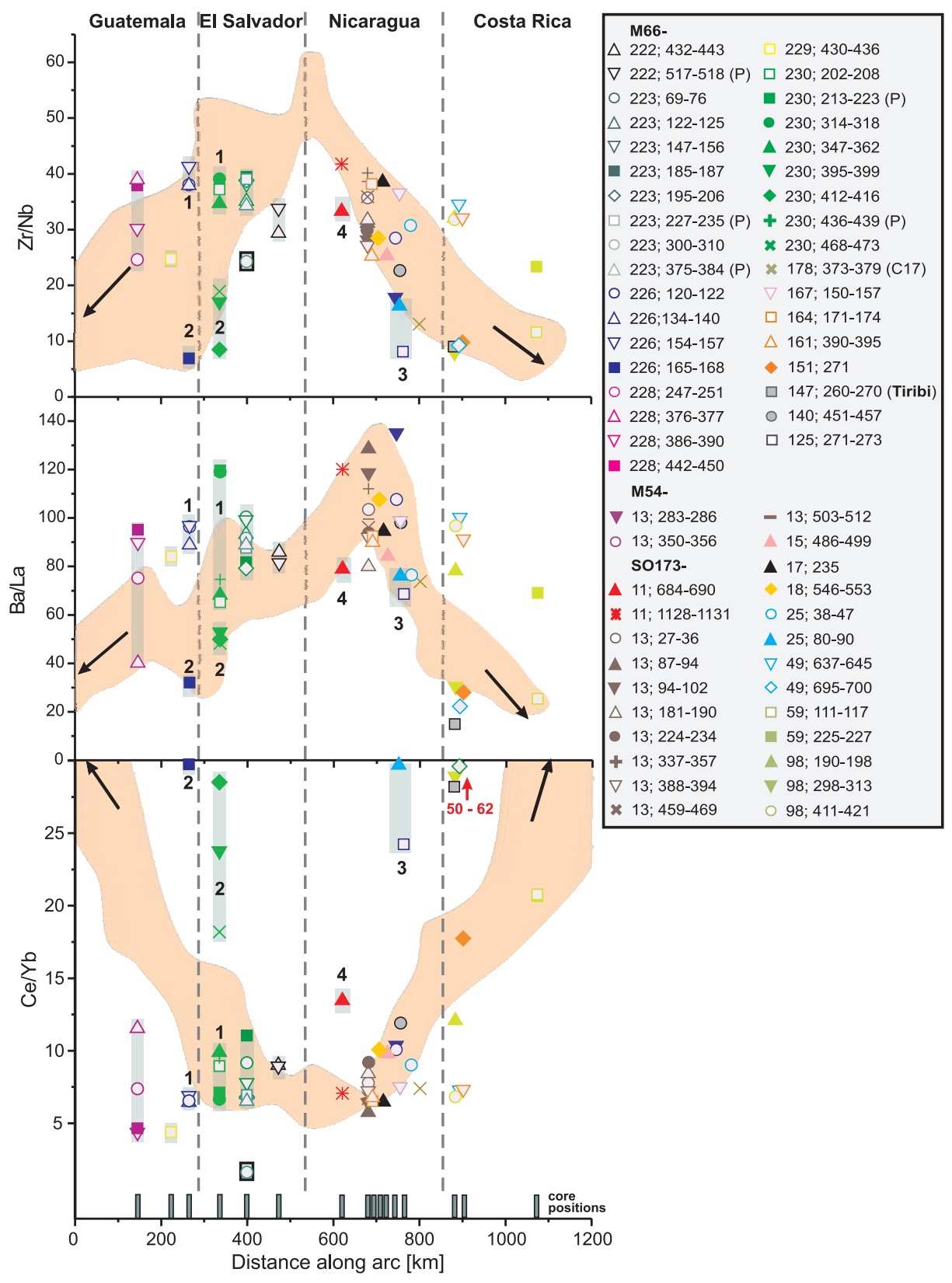

Figure 9. Comparison of average glass compositions of 60 out of 82 uncorrelated ash beds with $\mathrm{Zr} / \mathrm{Nb}, \mathrm{Ba} / \mathrm{La}$, and $\mathrm{Ce} / \mathrm{Yb}$ variations along the CAVA as discussed in the text. Arrows indicate continuing trends toward Costa Rica and Mexico. Bars at distance axis represent the core positions projected onto the arc along the subduction vector. Numbered tephras originate from northern El Salvador (1), central to northern Guatemala (2), Costa Rica (3), and northern Costa Rica or northern El Salvador (4) as discussed in the text.

the large distances between northern and southern CAVA areas, we favor the source area closest to core position that corresponds to ash layer compositions.

[53] We have plotted ash-layer glass-shard compositions in Figure 9 by projecting core positions onto the arc along the subduction vector. Best fits to all three trace element ratios suggest that ash beds in cores M66/3b-228, 229, 223 and 222, and ash layers composing group 1 (Figure 9) in each of M66/3b-226 and 230, originated in northern El Salvador, although contributions from Nicaragua particularly to the southern cores cannot be excluded. Ash layers forming group 2 (Figure 9) in each of M66/3b-226 and 230 are derived from source volcanoes in central to northern Guatemala, with pos- 

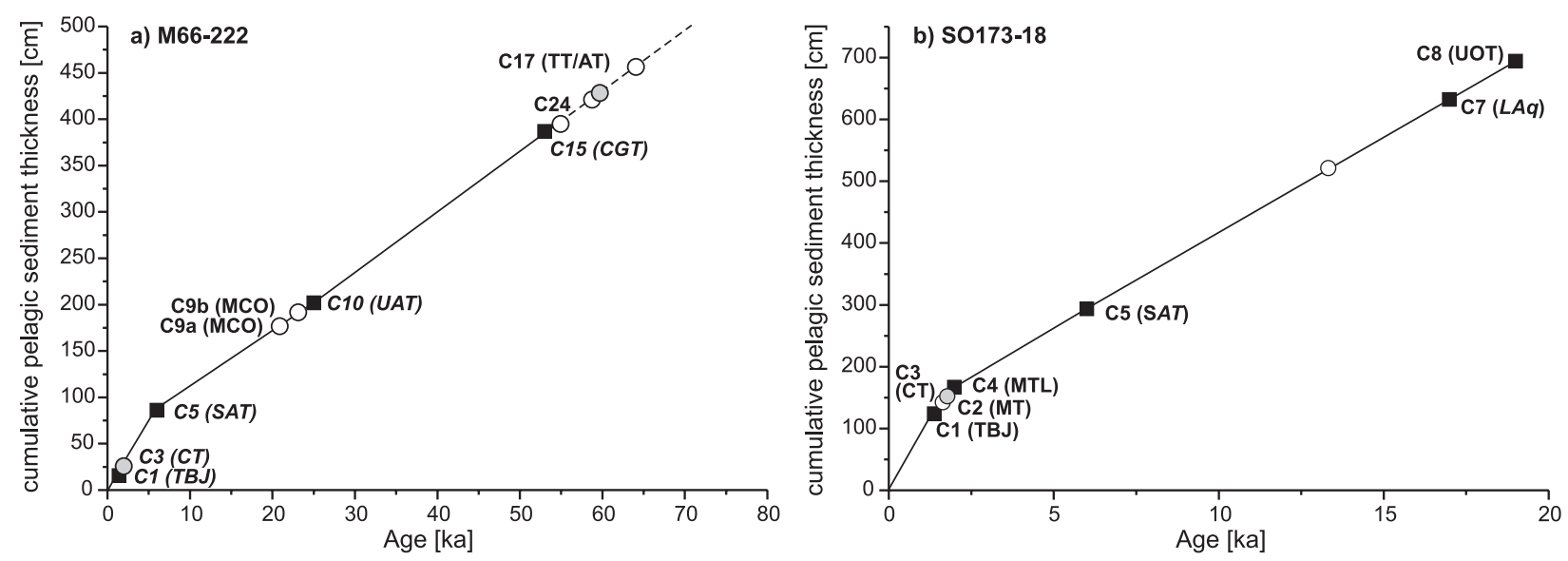

Figure 10. Cumulative pelagic sediment thickness versus age. Filled squares show ash layers correlated to onshore tephras (compare to Figures 1 and 7) of known age. Gray circles represent felsic and white circles represent mafic ash layers of unknown ages which can here be constrained by linear interpolation assuming constant sedimentation rates. Dashed lines extrapolate sedimentation rates to deeper core sections without age constraints. (a) Steady sedimentation rate at the lower slope offshore El Salvador allows us to date at least layers C9a,b and C7. (b) Layers C2 and C3 can be dated at the Nicaraguan slope. LAq and UOT ages from auxiliary material Figures S1b, S1f, and S1g are projected into Figure $10 \mathrm{~b}$ and fit the sedimentation rate. Respective diagrams for other cores are shown in auxiliary material Figures S1a-S1g.

sible contributions from Mexico. The presence of these offshore ash layers shows that there were more highly explosive eruptions in El Salvador and Guatemala during the past $400 \mathrm{ka}$ than have yet been documented on land.

[54] Almost all ash layers offshore Nicaragua, and the high $\mathrm{Ba} / \mathrm{La}$ ash beds offshore Costa Rica, have the trace element characteristics of Nicaraguan arc rocks. High $\mathrm{Ce} / \mathrm{Yb}$ ashes (marked 3 in Figure 9) offshore Nicaragua can be attributed to a source in Costa Rica, whereas the ash layer marked 4 in Figure 9 best fits an origin in northern El Salvador.

[55] Most of the uncorrelated ash layers occur at deep levels in our cores. There are approximately time-equivalent volcaniclastic successions in central Nicaragua, such as the Malpaisillo, Mateare and Las Sierras formations [Kutterolf et al., 2007a], that include numerous plinian tephras but these still need to be studied in detail.

\section{Ash-Layer Dating}

[56] The age range represented in our cores extends to $>322 \mathrm{ka}$, the time mark set by the distal ash of the Tiribi Tuff. Other time marks are given by the ash layers correlated to dated tephras on land. The age of yet undated ash layers can be estimated from their relative position between known time marks using linear interpolation, which assumes that sedimentation rates remained constant during the time interval considered. The relative position is determined from the thickness of pelagic sediments alone, ignoring the thickness of other intercalated ash beds (Figures 10 and S2).

[57] Core 228 contains the $191 \mathrm{ka} \mathrm{L-Tephra} \mathrm{(C23),}$ the 84 ka Los Chocoyos Tephra (C21), the $53 \mathrm{ka}$ Congo Tephra (C15), and the $1.5 \mathrm{ka}$ TBJ (C1) as well-dated horizons (Figure S2e). The Mixta Tephra (C13) has been dated at 27 ka by Peterson and Rose [1985]. Bioturbation is observed in the pelagic sediment but apparently did not affect its thickness. The position of layer C12 (Figure 8) in this core suggests an age of $25 \mathrm{ka}$ (Figure S2e) for the TB4 Tephra. Considering that the TB-tephras at Ilopango volcano are all separated by thick paleosols, tephras from other volcanoes, and reworked volcaniclastic sediments, this age for the TB4 tephra appears to be rather young. The TB4 (C12) ash layer in core 229 has been tilted during coring such that sediment thickness cannot be precisely measured. An approximate determination, however, yields an age of $43 \mathrm{ka}$ for the TB4 Tephra (Figure S2a), which is more compatible with field observations. The younger apparent TB4 age in core 228 possibly arises from an erroneous age of the Mixta Tephra. Peterson and Rose [1985] actually dated carbonized wood in a pyroclastic flow deposit that overlies the Mixta fall north of the Ayarza caldera. They also noted a meter-thick paleosol separating the Mixta from the Pinos Altos tephra, which is in turn covered by the Tapalapa 
ash dated at $23 \mathrm{ka}$. We observed a large erosional unconformity covered with volcaniclastic sediments between Mixta and Pinos Altos tephras south of the caldera, and another unconformity between Pinos Altos and Tapalapa tephras. We consider that the 4000 year age difference is rather short for the formation of the thick paleosol and the large unconformities. We cannot presently resolve this age problem but if we ignore the $27 \mathrm{ka}$ Mixta age, and use layer C15 (well-dated Congo Tephra; $53 \pm 3 \mathrm{ka}$ from ${ }^{14} \mathrm{C}$ dating of charcoal) as reference in core 228, we obtain a more realistic age of $36 \mathrm{ka}$ for the TB4 Tephra. The Mixta Tephra (C13) then appears to be $\sim 39$ ka old, which we feel fits better the observed on-land succession. We can also date the Conacaste Tephra (C14) as $51 \mathrm{ka}$, which fits well the observation in the field that the Conacaste Tephra is only separated by a thin paleosol and/or an erosive unconformity from the underlying Congo Tephra.

[58] We did not find the previously undated E-Fall from Amatitlán Caldera in our cores but identified it in core D-3 of Bowles et al. [1973], where it occurs $165 \mathrm{~cm}$ bsf. It is surrounded by the Los Chocoyos and L-Tephras, that occur at 460 and $560 \mathrm{~cm}$ bsf in that core, yielding an estimated age of the E-Tephra of $51 \mathrm{ka}$. This is considerably older than the age of $30 \mathrm{ka}$ guessed by Rose et al. [1999].

[59] Well-dated tephras in core 222 are the $53 \mathrm{ka}$ Congo Tephra (C15, Figure 10), the $25 \mathrm{ka}$ Upper Apoyo Tephra (C10) and the $1.5 \mathrm{ka}$ TBJ Tephra (C1). These would constrain the age of the San Antonio Tephra (C5) to $11.4 \mathrm{ka}$. However, from field relationships in Nicaragua [Kutterolf et al., 2007b; Pérez and Freundt, 2006] we know that the San Antonio Tephra must be close to $6 \mathrm{ka}$ but younger than $6.1 \mathrm{ka}$, hence the sedimentation rate above $\mathrm{C} 10$ has been overestimated probably due to incomplete compaction of the young sediment. Using an estimated $6 \mathrm{ka}$ age of the San Antonio Tephra, which is probably supported by lake drilling in Lake Nicaragua (S. Wulf, personal communication, 2007), as an additional time mark, we estimate ages of 21 and $22 \mathrm{ka}$ for the older mafic Cosigüina tephras $\mathrm{C} 9 \mathrm{a}$ and $\mathrm{C} 9 \mathrm{~b}$, respectively (Figure 10). From the lower part of core 222, we obtain an age of $60 \mathrm{ka}$ for the Twins/A-Tephra (C17 in Figures 8 and 10), which agrees with the K-Ar date of $75 \mathrm{ka}$ of the underlying Blanca Rosa Tephra. The mafic ash layer C24 (Figure 8) that is found in several cores of M66/3b and is probably derived from a source vent in El Salvador, is $\sim 55 \mathrm{ka}$ old.
[60] The Masaya Tuff MT/TIL (C2) and the Chiltepe Tephra (C3) are overlain by the $1.55 \mathrm{ka}$ TBJ (C1) and underlain by the $2.1 \mathrm{ka} \mathrm{MTL/LCT} \mathrm{(C4)}$ and $\sim 6$ ka SAT (C5) tephras in cores M54-2, SO173-11, 17 and 18 (Figures 10, S2b, S2d, and $\mathrm{S} 2 \mathrm{f})$. Although the apparent sedimentation rates of this time interval differ between the cores, all yield estimated ages of $1.8 \mathrm{ka}$ for the MT/TIL and $1.9 \mathrm{ka}$ for the Chiltepe Tephra with \pm 50 years deviation.

[61] Distal ashes of the Lower Apoyeque Tephra (LAq) from the Chiltepe volcanic complex, and the UOT pumice fall from Concepciòn volcano, both lie between the $24.5 \mathrm{ka}$ old Upper Apoyo Tephra and $\sim 6$ ka old San Antonio Tephra in core M5413. Since the age of the SAT is not precisely known, we also consider the additional constraint by the MTL/LCT $(2.1 \mathrm{ka})$ in core SO173-18. This constrains the age of the LAq to $16.5-17.4 \mathrm{ka}$ (Figures 10 and S2g) and of the UOT to $17.2-20.7 \mathrm{ka}$.

[62] The basaltic plinian Fontana Tephra occurs between the 84 ka Los Chocoyos Tephra (C21) and the 25 ka UAT (C10; core M54/11, Figure S2c) or the $\sim 6$ ka SAT (C5; core SO173-11, Figure S2d) yielding ages of $68 \mathrm{ka}$ and $55 \mathrm{ka}$, respectively. We note that the occurrence of correlated FT ash in core M54-2 directly below UAT must reflect disturbed pelagic sedimentation since observations on land (soil development and thick intervening sediments) demonstrate a longer time period between those tephras (Figure S2). In summary, estimated ages of around $60 \mathrm{ka}$ are considerably older than ages of 25-40 ka guessed in earlier studies in the absence of dating [Bice, 1985; Wehrmann et al., 2006]. This older age of the Fontana Tephra supports the conclusion of Wehrmann et al. [2006] that the eruptive vent was to the west rather than within Masaya Caldera, probably inside the older Las Nubes caldera.

\section{Correlations Between Cores and Central American Tephrostratigraphy}

[63] Tephrostratigraphic successions of single eruption centers or limited arc segments are shown in Figure 11 for different parts of Central America. Until now, temporal relationships between these successions are exclusively based on the radiometrically dated tephras. Our correlations with the marine record produce much more detailed stratigraphic links between the successions, yielding a consistent tephrostratigraphy along the CAVA. Especially correlated ash layers C1, C3, C5, C10, $\mathrm{C} 21$ and C23 facilitate widespread correlations 


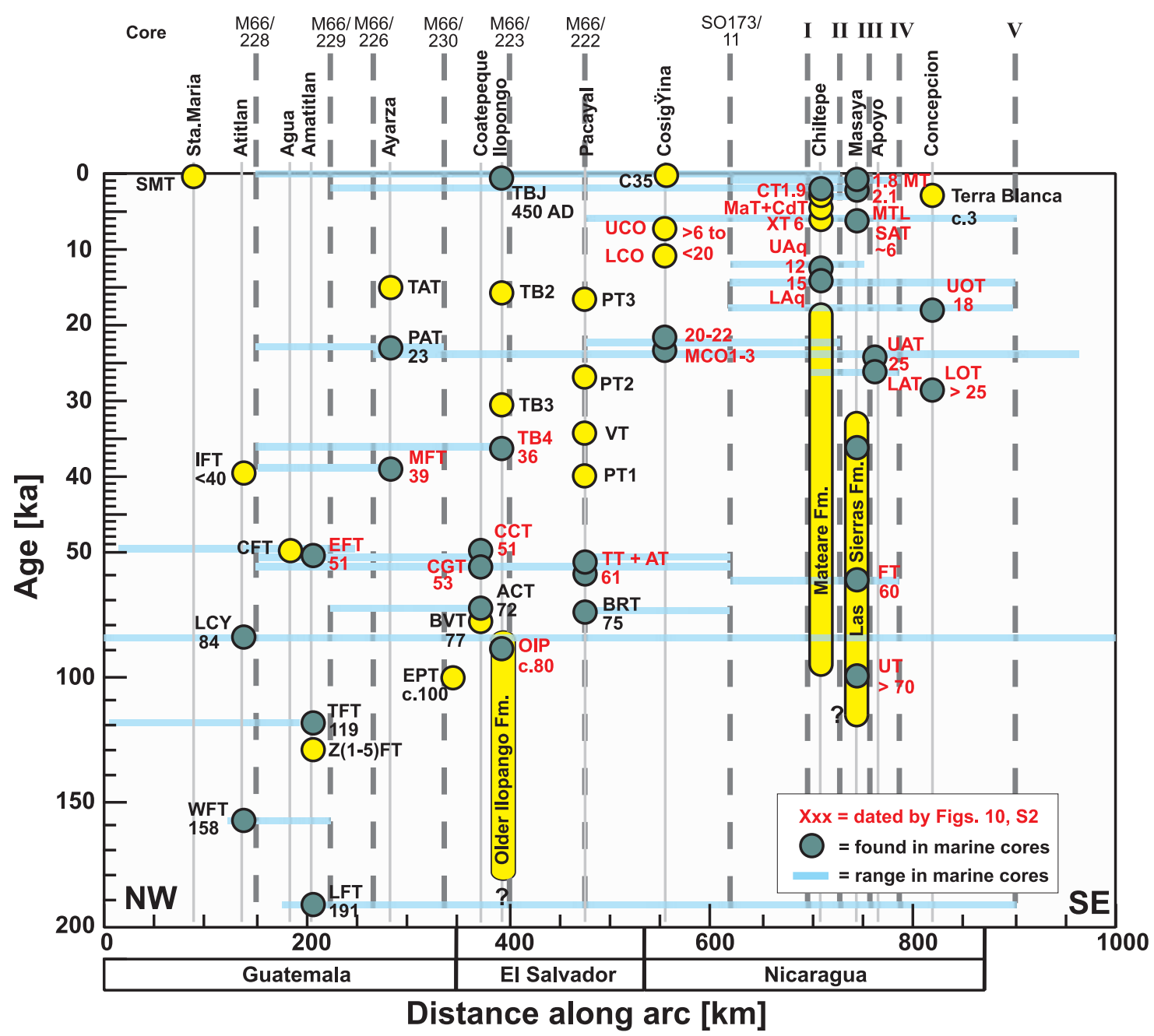

Figure 11. Composite tephrostratigraphy of Central America showing the position along the arc versus age of tephras. See Figure 1 for acronyms. Green dots mark tephras correlated with the marine record. Red labels show tephras newly dated (Figure 10). Blue lines show along-arc spread of ash layers on the Pacific seafloor. Gray bolddashed lines indicate projected core positions; Roman numerals represent groups of closely adjacent cores (I, SO17313, 17, 18; M66-161-164; II, SO173-15, M54-2,11; III, M54-13, M66-115, 118, 125, 129, 131-133, 139-140, 161,167, 220, SO173-35-36, 52; IV, SO173-25, 39, M66-174, 178-179; V, SO173-52, 98, 49, M66-147, 151-153, 190).

between the southern (Nicaragua and Costa Rica) and northern (Guatemala and El Salvador) tephra successions (Figure 11). Together with the new age estimations this is an important step in understanding the temporal evolution of plinian volcanism in Central America which we will discuss elsewhere.

\section{Conclusions}

[64] Having established a reference database of bulk rock, glass and mineral compositions of stratigraphically controlled widespread, mostly plinian tephras produced since the Pleistocene along the Central American Volcanic Arc, we were able to correlate 129 ash horizons in sediment gravity cores collected during three marine cruises along the Middle America Trench to tephras on land. In addition, we have used published compositional data [Bowles et al., 1973; Ledbetter, 1985] to correlate ash layers from DSDP Legs 66, 67 and 84 and gravity cores to deposits on land. In the 56 cores from cruises M54/2, M66/3a and SO173/3 offshore Guatemala, El Salvador, Nicaragua and Costa Rica we identified the distal ashes of 11 Nicaraguan, 8 El Salvadorian, 6 Guatemalan, and 1 Costa Rican eruptions. Ash layers correlated to dated tephras on land provide time marks in the sediment cores from which the ages of previously 
undated tephras can be estimated. New ages thus found were $\sim 1.8 \mathrm{ka}$ for the Masaya Tuff/Ticuantepe Lapilli, $\sim 1.9$ ka for the Chiltepe Tephra, $\sim 17 \mathrm{ka}$ for the Lower Apoyeque Tephra, $\sim 19 \mathrm{ka}$ for a dacitic plinian eruption of Concepciòn volcano, 21-22 ka for mafic Cosigüina tephras, $\sim 39 \mathrm{ka}$ for Mixta Tephra, $\sim 36 \mathrm{ka}$ for TB4-Tephra, $\sim 51 \mathrm{ka}$ for Conacaste and E-Tephra and $\sim 60 \mathrm{ka}$ for the mafic plinian Fontana Tephra. The combination of both, new age estimates and widespread correlations offshore Central America yield a tephrostratigraphic framework for the Central American volcanic arc.

\section{Acknowledgments}

[65] We gratefully acknowledge support during field work by the Instituto Nicaragüense de Estudios Territoriales (INETER) in Managua, particularly by Wilfried Strauch and all the drivers who accompanied us during field work, Servicio Nacional de Estudios Territoriales (SNET) in San Salvador, particularly Carlos Pullinger and Walter Hernandez, Instituto National de Sismologia, Volcanologia, Meteorologia e Hidrologia (INSIVUMEH) in Guatemala City, particularly Eddie Sanchez and Ottoniel Matias, as well as Instituto Costarricense de Electricidad (ICE) in San Jose, particularly Guillermo Alvarado. W.P. acknowledges a Ph.D. stipend by the Deutscher Akademischer Austauschdienst (DAAD). We especially thank all members of the scientific parties of $\mathrm{R} / \mathrm{V}$ METEOR cruises M66/3 and M54/2 as well as R/V SONNE cruise SO173/3 for the good and successful working atmosphere. Eric Steen and Mark Schmidt did the coring. We also thank Oliver Bardtoff, Cosima Burkert, Kristina Bernoth, Emelina Cordero, Joana Deppe, Yann Lahaye, Julia Mahlke, Dagmar Rau, and Mario Thöner, who assisted sampling on board, sample preparation, and analytical work. We also appreciate the helpful comments and suggestions of Stephen Blake, Mike Carr, Phil Shane, and Tom Vogel, who reviewed this paper. This publication is contribution 99 of the Sonderforschungsbereich 574 "Volatiles and Fluids in Subduction Zones" at Kiel University. R/V METEOR and R/V SONNE cruises were funded by the Deutsche Forschungsgemeinschaft (DFG).

\section{References}

Anderson, R. Y., E. B. Nuhfer, and W. E. Dean (1984), Sinking of volcanic ash in uncompacted sediment in Williams Lake, Washington, Science, 225, 505-508.

Barckhausen, U., C. R. Ranero, R. von Huene, S. Cande, and H. Roeser (2001), Revised tectonic boundaries in the Cocos Plate off Costa Rica: Implications for the segmentation of the convergent margin and for plate tectonic models, J. Geophys. Res., 106(19), 207-220.

Bice, D. C. (1980), Tephrostratigraphy and physical aspects of recent volcanism near Managua, Nicaragua, 422 pp., Ph.D. thesis, Univ. of Calf., Berkeley, Berkeley.

Bice, D. C. (1985), Quaternary volcanic stratigraphy of Managua, Nicaragua: Correlation and source assignment for mul- tiple overlapping plinian deposits, Geol. Soc. Am. Bull., 96, 553-566.

Blum, P. (1997), Physical properties handbook: A guide to the ship board measurement of physical properties of deepsea cores, in ODP Tech. Note 26, Ocean Drill. Program, College Station, Tex. (Available at http://www.odp.tamu. edu/publications/tnotes/tn/INDEX.HTM)

Bonis, S. B., O. Bohnenberger, and G. Dengo (1970), Mapa geologico del la Republica de Guatemala (1:500,000), Inst. Geogr. Nacl., Guatemala City, Guatemala.

Borgia, A., and B. van Wyk de Vries (2003), The volcanotectonic evolution of Concepción, Nicaragua, Bull. Volcanol., 65, 248-266.

Bosse, H. R., W. Lorenz, A. Merino, A. Mihm, K. Rode, M. Schmidt-Thome, H. S. Weber, and G. Wiesemann (1976), Geologische Karte der Republik El Salvador/Mittel Amerika, Bundesanst. für Geowiss. und Rohstoffe (BGR), Hannover, Germany.

Bowles, F. A., R. N. Jack, and I. S. E. Carmichael (1973), Investigation of deep-sea volcanic ash layers from equatorial Pacific cores, Geol. Soc. Am. Bull., 84, 2371-2388.

Cadet, J.-P., A. Pouclet, Y. Thisse, J. M. Bardintzeff, and J. Azéma (1982a), Middle America Neogene explosive volcanism and ash layers: Evidence from the Middle America Trench transect, Deep Sea Drilling Project 67, Initial Rep. Deep Sea Drill. Proj., 67, 475-491.

Cadet, J.-P., Y. Thisse, A. Pouclet, J. M. Bardintzeff, and J. F. Stephan (1982b), Tephra from Deep Sea Drilling Project Leg 66: Middle American Trench Transect (Southern Mexico), Initial Rep. Deep Sea Drill. Proj., 66, 687-698.

Cambray, H., J.-P. Cadet, and A. Pouclet (1993), Ash layers in deep-sea sediments as tracers of arc volcanic activity: Japan and Central America as case studies, Island Arc, 2(2), 72 86

Carr, M., M. D. Feigenson, L. C. Patino, and J. A. Walker (2003), Volcanism and geochemistry in Central America: Progress and problems, in Inside the Subduction Factory, Geophys. Monogr. Ser., vol. 138, edited by J. Eiler, pp. 153-174, AGU, Washington, D. C.

Carr, M. J. (1984), Symmetrical and segmented variation of physical and geochemical characteristics of the Central American Volcanic Front, J. Volcanol. Geotherm. Res., 20, $231-252$.

Carr, M. J., M. D. Feigensohn, and E. A. Benett (1990), Incompatible element and isotopic evidence for tectonic control of source mixing and melt extraction along the Central American arc, Contrib. Mineral. Petrol., 105, 369-380.

Carr, M. J., L. C. Patino, and M. D. Feigenson (2007), Petrology and geochemistry of lavas, in Central America-Geology, Resources and Hazards, vol. 2, edited by J. Buntschuh and G. E. Alvarado, pp. 565-590, A. A. Balkema, Rotterdam, Netherlands.

Commision Ejecutiva Hidroelectrica del Rio Lempa (CEL) (1992), Desarrollo de los Recursos Geotermicos del Area Centro-Occidental de El Salvador, Prefactibilidad Geotermica del Area de Coatepeque, Reconocimiento Geotermico, San Salvador.

CEL (1995), Prestacion de Servicios de Consultoria para desarrollar Estudios Geocientificos Complementarios en el Campo Geotermico Berlin-Partida 4: Estudio Geovulcanica, y Recursos Geotermicos del Area Berlin-Chinameca, Prefactibilidad Geotermica del Area de Coatepeque, Reconocimiento Geotermico, Informe Definitivo, internal report, San Salvador. 
Chiesa, S. (1991), El Flujo de Pomez biotitica del Rio Liberia (Guanacaste) Costa Rica, America Central, Rev. Geol. Am. Cent., 13, 73-84.

Chiesa, S., G. Civelli, P.-Y. Gillot, O. Mora, and G. E. Alvarado (1992), Rocas piroclásticas asociadas con La Formación de la Caldera de Guayabo, Cordillera de Guanacaste, Costa Rica, Rev. Geol. Am. Cent., 14, 59-75.

Clift, P. D., L.-H. Chan, J. Blusztajn, G. D. Layne, M. Kastner, and R. K. Kelly (2005), Pulsed subduction accretion and tectonic erosion reconstructed since $2.5 \mathrm{Ma}$ from the tephra record offshore Costa Rica, Geochem. Geophys. Geosyst., 6, Q09016, doi:10.1029/2005GC000963.

DeMets, C. (2001), A new estimate for present-day CocosCaribbean plate motion: Implications for slip along the Central American volcanic arc, Geophys. Res. Lett., 28, 4043-4046.

Drexler, J. W., W. I. Rose Jr., R. S. J. Sparks, and M. T. Ledbetter (1980), The Los Chocoyos Ash, Guatemala: A major stratigraphic marker in Middle America and in the three ocean basins, Quat. Res., 13, 327-345.

Dull, R. A., J. R. Southon, and P. D. Sheets (2001), Volcanism, ecology and culture: A reassessment of the Volcán Ilopango TBJ eruption in the Southern Maya Realm, Latin Am. Antiquity, 12(1), 25-44.

Feigenson, M. D., and M. J. Carr (1986), Positively correlated $\mathrm{Nd}$ and $\mathrm{Sr}$ isotope ratios of lavas from the Central American volcanic front, Geology, 14, 79-82.

Feigenson, M. D., M. J. Carr, S. V. Maharaj, S. Juliano, and L. L. Bolge (2004), Lead isotope composition of Central American volcanoes: Influence of the Galapagos plume, Geochem. Geophys. Geosyst., 5, Q06001, doi:10.1029/ 2003GC000621.

Freundt, A., S. Kutterolf, H. U. Schmincke, T. H. Hansteen, H. Wehrmann, W. Perez, W. Strauch, and M. Navarro (2006a), Volcanic hazards in Nicaragua: Past, present, and future, in Volcanic Hazards in Central America, edited by W. I. Rose et al., Spec. Pap. Geol. Soc. Am., 412, 141-165.

Freundt, A., S. Kutterolf, H. Wehrmann, H.-U. Schmincke, and W. Strauch (2006b), Eruption of the dacite to andesite zoned Mateare Tephra, and associated tsunamis in Lake Managua, Nicaragua, J. Volcanol. Geotherm. Res., 149, 103-123.

Fujioka, K. (1986), Synthesis of Neogene explosive volcanism of the Tohoku arc, deduced from marine tephra drilled around the Japan Trench region, Deep Sea Drilling Project Legs 56, 57, and 87B, Initial Rep. Deep Sea Drill. Proj., 87, $703-726$.

Guzman-Speziale, M., W. Pennington, and T. Matuomoto (1989), The triple junction of the North America, Cocos and Caribbean plates: Seismicity and tectonics, Tectonics, 8(5), $981-997$.

Hahn, G. A., W. I. Rose, and T. Meyers (1979), Geochemical correlation of genetically related rhyolitic ash-flow and airfall ashes, central and western Guatemala and the equatorial Pacific, in Ash-Flow Tuffs, edited by C. E. Chapin and W. E. Elston, Spec. Pap. Geol. Soc. Am., 180, 101-112.

Hannah, R. S., T. A. Vogel, L. C. Patino, G. E. Alvarado, W. Peréz, and D. R. Smith (2002), Origin of silicic volcanic rocks in central Costa Rica: A study of a chemically variable ash-flow sheet in the Tiribi Tuff, Bull. Volcanol., 64, 117-133.

Hart, W. J. E. (1983), Classic to postclassic tephra layers exposed in archeological sites, eastern Zapolitán Valley, in Archeology and Volcanism in Central America-The Zapotitán Valley of El Salvador, edited by P. D. Sheets, pp. 4451, Univ. of Tex. Press, Austin.

Hart, W. J. E., and V. Steen-McIntyre (1983), Terra Blanca Joven tephra from the AD 260 eruption of Ilopongo Caldera, in Archeology and Volcanism in Central America-The Zapotitán Valley of El Salvador, edited by P. D. Sheets, pp. 15-34, Univ. of Tex. Press, Austin.

Hazlett, R. W. (1987), Geology of the San Cristobal volcanic complex, Nicaragua, J. Volcanol. Geotherm. Res., 33, $223-$ 230.

Hoernle, K., P. van den Bogaard, R. Werner, B. Lissinna, G. E. Alvarado, and C.-D. Garbe-Schönberg (2002), Missing history $(16-71 \mathrm{Ma})$ of the Galapagos hotspot: Implications for the tectonic and biological evolution of the Americas, Geology, 30(9), 795-798.

Houghton, B. F., C. J. N. Wilson, R. T. Smith, and J. S. Gilbert (2000), Phreatoplinian eruptions, in Encyclopedia of Volcanoes, edited by H. Sigurdsson et al., pp. 513-525, Academic, Orlando, Fla.

Hunt, J. B., and Y. M. R. Najman (2003), Tephrochronological and tephrostratigraphical potential of Pliocene-Pleistocene volcaniclastic deposits in the Japan Forearc, ODP Leg 186, Proc. Ocean Drill. Program Sci. Results, 186, 29 pp., doi:10.2973/odp.proc.sr.186.107.2003.

Jordan, B. R., H. Sigudsson, S. N. Carey, R. Rogers, and J. Ehrenborg (2006), Geochemical correlation of Caribbean Sea tephra layers with ignimbrites in Central America, in Neogene-Quaternary Continental Margin Volcanism: A Perspective From México, edited by C. Siebe et al., Spec. Pap. Geol. Soc. Am., 402, 175-208.

Kempter, K. A., S. G. Benner, and S. N. Williams (1996), Rincón de la Vieja volcano, Guanacaste province, Costa Rica: Geology of the southwestern flank hazards implications, J. Volcanol. Geotherm. Res., 71, 109-127.

Koch, A. J., and H. McLean (1975), Pleistocene tephra and ash-flow deposits in the volcanic highlands of Guatemala, Geol. Soc. Am. Bull., 86, 529-541.

Kutterolf, S., A. Freundt, W. Peréz, H. Wehrmann, and H.-U. Schmincke (2007a), Late Pleistocene to Holocene temporal succession and magnitudes of highly-explosive volcanic eruptions in west-central Nicaragua, J. Volcanol. Geotherm. Res., 163, 55-82.

Kutterolf, S., U. Schacht, H. Wehrmann, A. Freundt, and T. Mörz (2007b), Onshore to offshore tephrostratigraphy and marine ash layer diagenesis in Central America, in Central America-Geology, Resources and Hazards, vol. 2, edited by J. Buntschuh and G. E. Alvarado, pp. 395-423, A. A. Balkema, Lisse, Netherlands.

Kutterolf, S., A. Freundt, U. Schacht, D. Bürk, R. Harders, T. Mörz, and W. Peréz (2008), Pacific offshore record of plinian arc volcanism in Central America: 3. Application to forearc geology, Geochem. Geophys. Geosyst., doi:10.1029/2007GC001826, in press.

Ledbetter, M. T. (1982), Tephrachronology at Sites 502 and 503, Initial Rep. Deep Sea Drill. Proj., 68, 403-408.

Ledbetter, M. T. (1985), Tephrochronology of marine tephra adjacent to Central America, Geol. Soc. Am. Bull., 96, 77-82.

Mann, C. P., J. Stix, J. W. Vallance, and M. Richer (2004), Subaqueous intracaldera volcanism, Ilopango Caldera, El Salvador, Central America, in Natural Hazards in El Salvador, edited by W. I. Rose et al., Spec. Pap. Geol. Soc. Am., $375,159-174$.

McKnight, S. B., and S. N. Williams (1997), Old cinder cone or young composite volcano?: The nature of Cerro Negro, Nicaragua, Geology, 25, 339-342.

Mehringer, P. J., A. M. Sarna-Wojcicki, L. R. Wollwage, and P. Sheets (2005), Age and extent of the Ilopango TBJ Tephra inferred from a Holocene chronostratigraphic reference section, Lago de Yojoa, Honduras, Quat. Res., 63(2), 199-205. 
Newhall, C. G. (1987), Geology of the Lake Atitlàn region, western Guatemala, J. Volcanol. Geotherm. Res., 33, 23-55.

Patino, L. C., M. Carr, and M. D. Feigenson (1997), Cross-arc geochemical variations in volcanic fields in Honduras C. A.: Progressive changes in source with distance from the volcanic front, Contrib. Mineral. Petrol., 129, 341-351.

Patino, L. C., M. Carr, and M. D. Feigenson (2000), Local and regional variations in Central American arc lavas controlled by variations in subducted sediment input, Contrib. Mineral. Petrol., 138, 256-283.

Pérez, W., and A. Freundt (2006), The youngest highly explosive basaltic eruptions from Masaya Caldera (Nicaragua): Stratigraphy and hazard assessment, in Volcanic Hazards in Central America, edited by W. I. Rose et al., Spec. Pap. Geol. Soc. Am., 412, 189-207.

Pérez, W., G. E. Alvarado, and P. B. Gans (2006), The 322 ka Tiribi Tuff: Stratigraphy, geochronology and mechanisms of deposition of the largest and most recent ignimbrite in the Valle Central, Costa Rica, Bull. Volcanol., 69, 25-40.

Peterson, P. S., and W. I. Rose (1985), Explosive eruptions of the Ayarza Calderas, southeastern Guatemala, J. Volcanol. Geotherm. Res., 25, 289-307.

Pouclet, A., J.-P. Cadet, and J. Bourgois (1985), Ash layers from Deep Sea Drilling Project Leg 84: Middle America Trench Transect, Initial Rep. Deep Sea Drill. Proj., 84, 609-618.

Pullinger, C. R. (1998), Evolution of the Santa Ana volcanic complex, El Salvador, 145 pp., M. S. thesis, Mich. Technol. Univ., Houghton.

Rabek, K., M. T. Ledbetter, and D. F. Williams (1985), Tephrochronology of the western Gulf of Mexico, Quat. Res., 23, 403-416.

Ranero, C. R., A. Villaseñor, J. Phipps Morgan, and W. Weinrebe (2005), Relationship between bend-faulting at trenches and intermediate-depth seismicity, Geochem. Geophys. Geosyst., 6, Q12002, doi:10.1029/2005GC000997.

Reynolds, J. H. (1987), Timing and sources of Neogene and Quaternary volcanism in south-central Guatemala, J. Volcanol. Geotherm. Res., 33, 9-22.

Rose, W. I. (1987a), Santa Maria, Guatemala: Bimodal sodarich calc-alkalic stratovolcano, J. Volcanol. Geotherm. Res., 33, 109-129.

Rose, W. I. (1987b), Volcanic activity at Santiaguito volcano, 1976-1984, Spec. Pap. Geol. Soc. Am., 212, 17-27.

Rose, W. I., T. J. Bornhorst, and J. W. Drexler (1982), Preliminary correlation of Quaternary volcanic ashes from the Middle America Trench off Guatemala, Deep Sea Drilling Project Leg 67, Initial Rep. Deep Sea Drill. Proj., 67, 493-495.

Rose, W. I., C. G. Newhall, T. J. Bornhorst, and S. Self (1987), Quaternary silicic pyroclastic deposits of Atitlàn Caldera, Guatemala, J. Volcanol. Geotherm. Res., 33, 57-80.
Rose, W. I., F. M. Conway, C. R. Pullinger, A. Deino, and K. McIntosh (1999), An improved age framework for late Quaternary silicic eruptions in northern Central America, Bull. Volcanol., 61, 106-120.

Rose, W. I. J., N. K. Grant, and J. Easter (1979), Geochemistry of the Los Chocoyos Ash, Quezaltenango Valley, Guatemala, in Ash-Flow Tuffs, edited by C. E. Chapin and W. E. Elston, Spec. Pap. Geol. Soc. Am., 180, 87-99.

Schacht, U. (2005), Alteration of volcanic glasses in marine sediments: Laboratory experiments and field studies, $160 \mathrm{pp}$., Ph.D., Univ. of Kiel, Kiel, Germany.

Scott, W., C. Gardner, A. Alverez, and G. Devoli (2006), A. D. 1835 eruption of Volcán Cosigüina, Nicaragua: A guide for assessing hazards, in Volcanic Hazards in Central America, edited by W. I. Rose et al., Spec. Pap. Geol. Soc. Am., 412, $167-187$.

Self, S., M. R. Rampino, and M. Carr (1989), A reappraisal of the 1835 eruption of Coseguina and its atmospheric impact, Bull. Volcanol., 52, 57-65.

Sigurdsson, H. (1997), Caribbean volcanism, Cretaceous/ Tertiary impact, and ocean-climate history: Synthesis of Leg 165, Proc. Ocean Drill. Program Initial Rep., 165, $377-402$

Sussman, D. (1985), Apoyo Caldera, Nicaragua: A major Quaternary silicic eruptive center, J. Volcanol. Geotherm. Res., 24, 249-282.

Vogel, T. A., L. C. Patino, G. E. Alvarado, and P. B. Gans (2004), Silicic ignimbrites within the Costa Rican volcanic front: Evidence for the formation of continental crust, Earth Planet. Sci. Lett., 226, 149-159.

Vogel, T. A., L. C. Patino, J. K. Eaton, J. W. Valley, W. I. Rose, G. E. Alvarado, and E. L. Viray (2006), Origin of silicic magmas along the Central American volcanic front: Genetic relationship to mafic melts, J. Volcanol. Geotherm. Res., $156,217-228$

Wehrmann, H., C. Bonadonna, A. Freundt, B. F. Houghton, and S. Kutterolf (2006), Fontana Tephra: A basaltic plinian eruption in Nicaragua, in Volcanic Hazards in Central America, edited by W. I. Rose et al., Spec. Pap. Geol. Soc. Am., 412, 209-223.

Williams, H. (1952), The great eruption of Cosequina, Nicaragua, in 1835, with notes on the Nicaraguan volcanic chain, Univ. Calif. Publ. Geol. Sci., 29, 21-45.

Williams, S. N. (1983), Geology and eruptive mechanisms of Masaya Caldera Complex, Nicaragua, 169 pp., Ph.D. thesis, Dartmouth Coll., Hanover, N. H.

Wundermann, R. L. (1982), Amatitlàn, an active resurgent caldera immediately south of Guatemala City, Guatemala, 192 pp., M. S. thesis, Mich. Technol. Univ., Houghton.

Wundermann, R. L., and W. I. Rose (1984), Amatitlán, an actively resurging caldera $10 \mathrm{~km}$ south of Guatemala City, J. Geophys. Res., 89, 8525-8539. 